IZA DP No. 251

\title{
Labor Markets, Inequality and Poverty in Georgia
}

\section{Ruslan Yemtsov}

J anuary 2001 


\title{
Labor Markets, Inequality and Poverty in Georgia
}

\author{
Ruslan Yemtsov \\ World Bank, Washington, D.C. and IZA, Bonn \\ Discussion Paper No. 251 \\ January 2001 \\ IZA \\ P.O. Box 7240 \\ D-53072 Bonn \\ Germany \\ Tel.: +49-228-3894-0 \\ Fax: +49-228-3894-210 \\ Email: iza@iza.org
}

This Discussion Paper is issued within the framework of IZA's research area Labor Markets in Transition. Any opinions expressed here are those of the author(s) and not those of the institute. Research disseminated by IZA may include views on policy, but the institute itself takes no institutional policy positions.

The Institute for the Study of Labor (IZA) in Bonn is a local and virtual international research center and a place of communication between science, politics and business. IZA is an independent, nonprofit limited liability company (Gesellschaft mit beschränkter Haftung) supported by the Deutsche Post AG. The center is associated with the University of Bonn and offers a stimulating research environment through its research networks, research support, and visitors and doctoral programs. IZA engages in (i) original and internationally competitive research in all fields of labor economics, (ii) development of policy concepts, and (iii) dissemination of research results and concepts to the interested public. The current research program deals with (1) mobility and flexibility of labor markets, (2) internationalization of labor markets and European integration, (3) the welfare state and labor markets, (4) labor markets in transition, (5) the future of work, (6) project evaluation and (7) general labor economics.

IZA Discussion Papers often represent preliminary work and are circulated to encourage discussion. Citation of such a paper should account for its provisional character. 
IZA Discussion Paper No. 251

January 2001

\title{
ABSTRACT \\ Labor Markets, Inequality and Poverty in Georgia
}

The labor market is the main channel through which economic growth affects poverty. This paper is the first empirical account of main channels through which the growth in transition period has affected labor market and living standards in Georgia. It is based on both the official aggregate statistics and data from a representative household survey fielded in 1996-1997. The paper finds that in Georgia the labor market has shown outstanding flexibility during a period of severe political and economic turmoil in 1992-1995. Despite the catastrophic fall in GDP employment contracted only marginally. This flexibility has been achieved mainly through the informalization of employment, and through the reallocation of labor towards small-scale agriculture. Informalization has dampened the impact of the crisis and served to protect the poor, stabilizing the poverty rate at the politically and socially acceptable level (around $15 \%$ of the population). However, the informalization limited the impact of market forces favoring human capital accumulation on the formation of earnings. Today, a large and growing fraction of the Georgian labor force relies on self-employment as the primary means to earn an income. For some, this is an avenue for earnings mobility and growth; for the majority, however, selfemployment remains constrained to low-productivity agricultural or trading activities, with little earnings stability and little potential for long term earnings growth. Prospects for the future hinge critically on the economy's ability to generate new private formal employment, and to reallocate labor away from these low-productivity activities into higher value added sectors.

JEL Classification: $\quad 13, \mathrm{~J} 4$

Keywords: Employment, unemployment, self-employment, informal sector, real wage, productivity, earnings, inequality, returns to education, poverty, gender gap

\author{
Ruslan Yemtsov \\ World Bank \\ 1818 H Street N.W. Room H4-239 \\ Washington D.C. 20433 \\ USA \\ Tel.: +1-202-458-7276 \\ Fax: +1-202-522-2755 \\ Email: Ryemtsov@worldbank.org
}




\section{Labor Markets, Inequality and Poverty}

Georgian labor market has shown an outstanding flexibility over the years of political and economic turmoil. The flexibility was achieved mainly by an overwhelming informalization of employment. This flexibility has greatly benefited the poor by reducing the brunt of crisis. But increasingly with the resumption of economic growth the very strengths of informalization start playing against the poor. This requires public action aimed at encouraging the formal employment and increasing the productivity of poor's main asset, labor, equipping the poor for modern private sector jobs and helping to diversify their sources of earnings.

\section{Introduction}

1. Theoretically, and empirically, one finds across countries a very strong link between developments in the labor market and changes in poverty (Deininger, Squire (1996); WDR 1995). This is not surprising, since for most households, poor and prosperous alike, income from work is the main determinant of their living conditions. Labor market thus acts as the main transmission mechanism between economic growth and poverty reduction. Growth reduces poverty through rising employment, increased labor productivity, and higher real wages.

2. In this chapter we analyze this link in the context of Georgia. We base our analysis primarily on official (IMF and SDS) macroeconomic data and the dataset from the SDS Survey of Georgian Households, which provided the primary data for the analysis presented in Chapter 1. The chapter is organized as follows. In Section 2.1 we look at the labor market status of the poor and try to see in what respect their position is different from that of non-poor. Section 2.2 sets out the initial labor market conditions that prevailed in the Former Soviet Union and Georgia, and follows trends over the transition. In sections 2.3-2.4 we analyze performance urban and rural labor markets and examine how different groups benefit from new employment opportunities opened with economic growth. Section 2.5. offers a closer look on what prevents some group of workers to benefit fully from these opportunities, focusing on labor earnings determination and resulting inequalities. Section 2.6 concludes with prospects of fully including the poor in the process of economic growth.

\subsection{Labor market status and poverty}

3. Poor and in non-poor alike in Georgia derive most of their income (up to 80 percent), from labor market sources, either through wages or through self-employment earnings. As a result, the risk of poverty at any moment is closely associated with the extent to which a household participates in the labor market, and the way in which the market remunerates its labor. Changes in poverty over time are linked to changing labor market position of household members. In Georgia, employment status is a strong correlate of poverty. This is mirrored in the differences between the poor and the non-poor with respect to: participation in the labor market, unemployment, sector of employment, labor relations, and income from employment. 
4. Participation and unemployment. The poor are both less economically active (lower participation rates, 69 percent as opposed to 74 percent) ${ }^{1}$ and more prone to unemployment. These differences in labor force participation between poor and non-poor become even more accentuated if we add an age dimension. Labor force participation rates vary significantly over the lifecycle. Figure 1 presents the share of economically active adults in each age category separately for the poor and the non-poor. White areas on the figure represent the population out of labor force, gray are employed, and black rectangles represent the unemployed (all as a share of total population in each age groups). For almost all age groups labor force participation for the poor is below participation of the non-poor. Differences between poor and non-poor are noticeable for prime working age individuals (between 25 and 50), but also for the old: for individuals 55 and over have distinctly lower participation rates than non-poor. This reflects the limited role that the government can play with its social security, which forces a significant proportion of elderly to keep working to stay out of poverty. A particularly striking difference arises in the prevalence of unemployment: the poor are much more likely to be unemployed than the non-poor for almost every age group.

Figure 1. Labor force participation, employment and unemployment by age

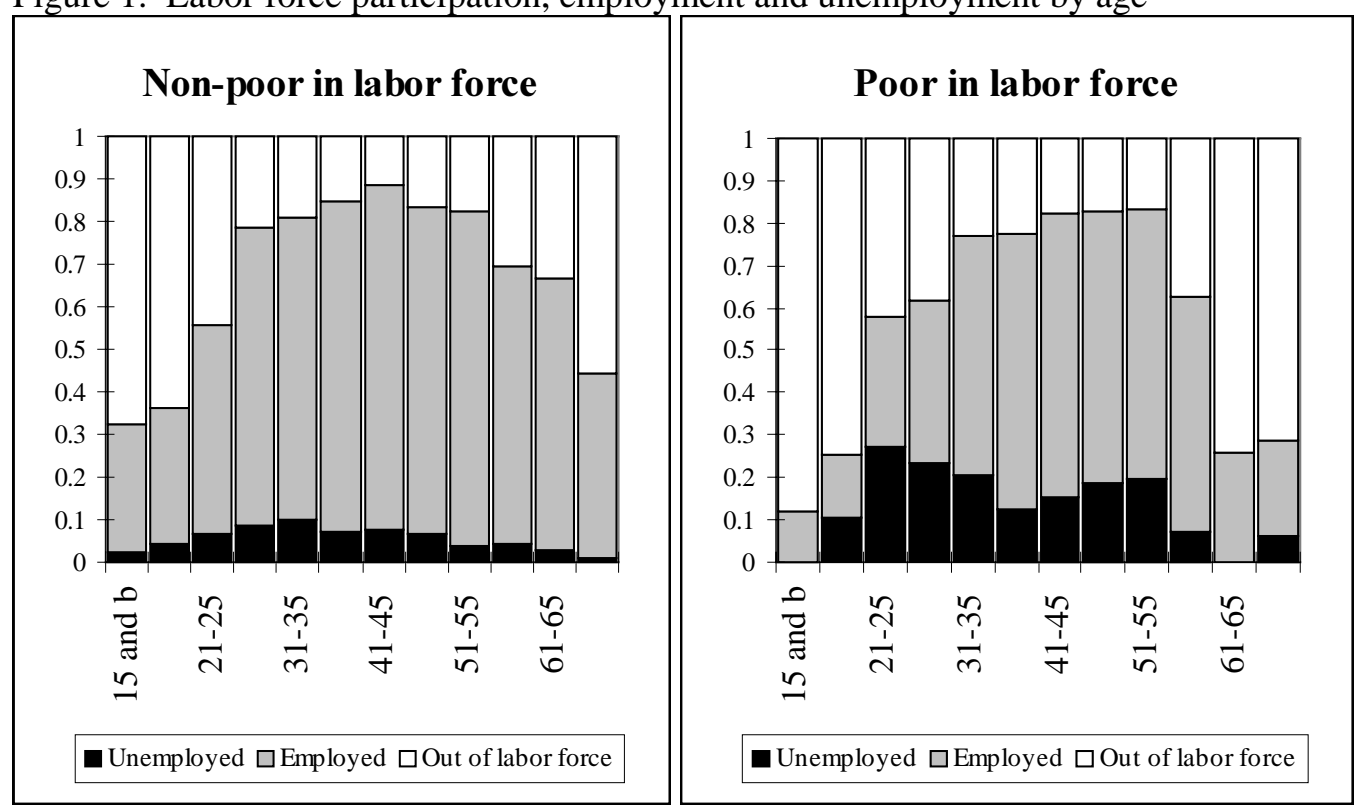

Source: SDS household survey. Notes: rates are averages for 3rd Q 1996 - 2nd Q 1997. The lowest limit of the working age is set at 14 years.

5. Differences between poor and non-poor in labor market status are even more pronounced for women. For working age females, the gap in economic activity is much wider than for males: only 60 percent of women from poor families are in the labor force, as opposed to 68 percent of non-poor females. In addition to these discrepancies, women have an unemployment rate that is twice the unemployment rate for men. Female employment is thus an important determinant of the ability of families to escape from poverty. Given these correlations between female labor force participation, unemployment and poverty, it is not surprising that of the male-headed households much fewer fall in poverty if their spouses work. There are, however, important reasons why this strategy cannot be adopted by all poor households.

1 SDS survey, labor force annex. All data are for the weekly status. 
6. In Georgian poor households we observe a striking counter-intuitive relationship between the participation rate and the level of education. This is largely explained by the fact that for poor women, there is an inverse relation between participation rate and education. Men from poor families are as likely to be participants at any level of education, but poor females with higher education have participation rate of only 50 percent, while for those with secondary education it equals 65 percent. Most of this negative association is explained by very low participation rates of female new entrants (between ages 25 and 30) with higher education, and very sharp drop in participation rate for poor females with higher education after 55 . In contrast, among poor females with secondary education, participation rates are growing with age. In addition, poor women with university education have 30 percent unemployment rate - much higher than females with secondary education. Note finally that for the women from non-poor households we observe the opposite and rather expected outcome: the higher is the education level, the higher are chances of being employed and lower - of being unemployed. Thus for the population as a whole education significantly increases the probability of women to be employed.

7. Therefore the benefits from working for some well-educated women are so low, that potential gains from employment outside the household cannot outweighs the corresponding costs. Lack of employment opportunities for certain professions that have been traditionally acquired by women and current low wage levels could be cited as possible reasons. Schools, kindergartens and universities traditionally employed about one half of women with higher education. With falling demand for teachers and low salary many have dropped out of employment. And the skills they have obtained are not always helpful to find employment elsewhere. Limited access to affordable childcare facilities is another deterrent for younger women to participate in the labor market.

8. Employment. However strong is the link between unemployment, non-participation and poverty, most of the poor in Georgia are working poor. Poor have a specific occupational profile that distinguishes them from non-poor.

Figure 2. Structure of employment for the poor and non-poor

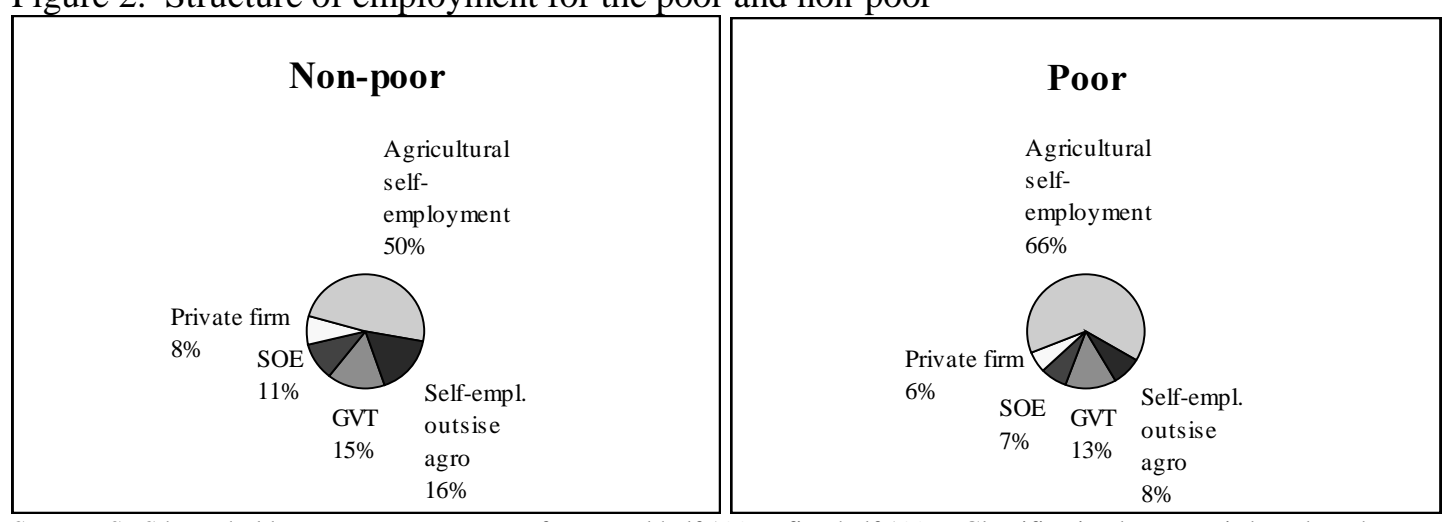

Source: SDS household survey. Note: average for second half 1996 - first half 1997. Classification by sector is based on the predominant employment over the last 3 months. SOE - state-owned or privatizing enterprise; GVT - budgetary sector.

9. Figure 2 presents a breakdown of all poor and non-poor employed by type of employment. It distinguishes between self-employment in agriculture and outside agriculture, and wage employment in private firms, State-owned enterprises (SOE) some of which are under privatization, and budgetary sector (mainly public administration, health and education). As the figure shows, in agriculture, the poor tend to be primarily self-employed; two thirds of the 
working poor earn their living this way. Not surprisingly, among the poor who are self-employed in agriculture, two thirds are unpaid family workers -- a much higher proportion than for the nonpoor, for whom this type of employment accounts for only one third of all self-employed in agriculture.

10. Poor are less likely than the non-poor to perform a salaried work regardless if the property form is State-owned, privatized, or private. But even when poor are employed by the Government or private firms, they tend to work in branches that offer less remunerative work, as we shall see in a moment. Finally, differences in the role of selfemployment outside agriculture are striking: poor are much less likely to hold such jobs.

11. Table 1 puts together the poverty risks for the employed by economic branch and the distribution of all employed by sectors. Agriculture features prominently as a sector where almost 70 percent of the poor are employed. For the non-poor this share does not exceed 50 percent. Trade is the second largest sector of employment for both the poor and non-poor, but it does not mean higher poverty risk. In some sectors where wages and earnings are high, all of the employed are non-poor -- financial services, hotels and restaurants being the most important. On the other hand, only for the poor mining and domestic help - sectors with highest poverty risks - play a noticeable role in the employment. The latter is quite important for urban women with low education, and which appears to be their major option for entry into the labor market.

Table 1. Branch of employment and employment profile for poor and non-poor, first half of 1997

\begin{tabular}{|l|ccc|}
\hline \multicolumn{1}{|c|}{ Sector } & $\begin{array}{c}\text { Poverty risk } \\
\text { (percent } \\
\text { poor) }\end{array}$ & $\begin{array}{c}\text { Share in total } \\
\text { employment for the } \\
\text { non-poor (percent) }\end{array}$ & $\begin{array}{c}\text { Share in total } \\
\text { employment for the } \\
\text { poor (percent) }\end{array}$ \\
\hline Agriculture & 7.5 & 53.3 & 68.3 \\
Mining & 16.8 & 0.9 & 2.8 \\
Manufacturing & 4.4 & 3.5 & 2.6 \\
Electricity, gas and water & 3.4 & 1.2 & 0.7 \\
Construction & 2.1 & 1.4 & 0.5 \\
Trade & 5.0 & 13.4 & 11.1 \\
Hotels and restaurants & 0.0 & 0.4 & 0.0 \\
Transportation, communication & 4.3 & 4.0 & 2.8 \\
Financial services & 0.0 & 0.4 & 0.0 \\
Real estate & 0.0 & 0.1 & 0.0 \\
Public administration, defense & 1.1 & 3.9 & 0.7 \\
Education & 3.7 & 7.7 & 4.7 \\
Health and social services & 2.0 & 4.5 & 1.5 \\
Other personal services & 2.2 & 3.7 & 3.0 \\
Domestic help & 13.6 & 1.2 & $\mathbf{1 0 0 . 0}$ \\
Total & $\mathbf{6 . 0}$ & $\mathbf{1 0 0 . 0}$ & \\
\hline
\end{tabular}

Source: SDS household survey. To avoid double-counting, only primary employment as reported by respondents was included to avoid double-counting of multiple job holders; the numbers may differ with the official employment figures by SDS based on enterprise reports.

12. Poor also tend to have less secure jobs -- they are the first to be put on involuntary leave or forced to work part time. For these reasons, it is instructive to see how many hours those who claim to have a wage contract actually worked in their primary employment during the reference month and to compare these for poor and non-poor. Poor tend to work shorter hours -- on 
average 36 hours per week as opposed to 40 for the non-poor. This difference is particularly striking for SOE and enterprises under privatization. Due to the prevalence of involuntary leaves, on average, workers in such enterprises have worked only 39 hours per week, while those who are poor have worked only 33 hours (excluding education and health, where a normal working week is often less than 30 hours). Substantial segments of the workforce with wage employment contracts worked part-time. The actual division between full-time and part-time workers shows high levels of part-time work and dramatic differences across sectors. ${ }^{2}$ Mining and manufacturing stand out as branches where the incidence of part-time work is much higher for those workers who are poor, and for these two groups reaches almost half of the number of employed.

13. Insecure employment can also appear in the form of casual or temporary jobs.

Sometimes a single job cannot provide enough earnings and workers hold many jobs, of which very often are temporary in nature. As SDS household survey has shown, among all the employed, about a quarter hold multiple (usually two) jobs. Given the low level of salary this finding is not surprising. But what is surprising is that the poor are more likely to have a second job; 40 percent of employed poor have at least two jobs. Because they are still below the minimum consumption basket, it is evident that this is not enough to lift them out of poverty.

14. Earnings. High disparity in wages between poor and non-poor is a reflection of the big differences in pay between branches of the national economy. The average monthly wage over the period of survey in education and health care was a meager 20-25 lari, as opposed to average wages in construction that exceeded 100 lari. But the differences in average wages between sectors are not what matters most for poverty risks. For example, wages in health care are as low as in education, but the employed in health care institutions have a much lower poverty risk than education workers, and in fact, a much lower risk than on average for the employed. Regardless of the branch of employment, between 5 and 10 percent of wage earners in leading branches (depending on the quarter) are poor.

15. Part of the differences in pay between poor and non-poor can be explained by differences in endowments. About one-third of total wage gap between the poor and non-poor is explained by differences in education, age, potential experience, gender, sector of employment and location. ${ }^{3}$ But the main reason behind the fact that poor earn less is that they work in less privileged, less paid and less secure positions.

16. The factor that compounds earning differentials between poor and non-poor is wage arrears. Close to 10 percent of all wage employees are subject to delayed payment of wages. Analysis of SDS household data on the pattern of wage arrears reveals distinct patterns -- arrears are evidently not random in impact. Wage employees when they are poor, tend to have a greater chance to be subject to wage arrears than do the non-poor. SDS survey has revealed that on average 22 percent of poor wage earners were owed back wages by their employers, while only 8 percent of non-poor were not receiving their wages on time, or were receiving them irregularly.

17. Very often these discriminated workers are women. There are striking inequalities between men and women in their wages. On average, women receive only $46 \%$ of men's monthly salary. This is a result of women predominantly being employed in the lower paid sectors (education and health), and on part-time basis, but also because of gender discrimination.

2 Part time work is defined as work where normal work hours per week do not exceed 30.

3 Result is based on the regression pooling all data and relating hourly wage (in logs) to a set of individual characteristics 
The educational achievements of Georgian women are actually slightly above those for men, but even for full-time workers at higher education grades within the same branch of national economy, women get paid 10-30\% less than men. ${ }^{4}$ This gap is pervasive, not only in private employment, but also among Government employees. Even controlling for location, branch, education and experience, we find that women earn 30 percent less than men in the budgetary sector. ${ }^{5}$ Such a gap is even higher in private or privatized enterprises.

18. Conclusion: labor market status and poverty over time. As the country emerges from severe collapse of the economy, the labor market plays an increasingly important role as the determinant of living standards of the population.

19. During the survey rounds, we observed that trends on the labor market have greatly impacted upon the poverty. Poverty among the wage employed has been reduced substantially (by 50 percent). But the increase in wage employment has been very modest.

20. The bulk of job creation has been accounted for by self-employment. And for the overall incidence of poverty the fact that among the self-employed the risk of poverty has in fact increased over the 1.5 years of the survey, is of paramount importance.

21. Changes in the risk of poverty for the dependents were conditioned upon the employment status of working household members. Those living with wage employees who have become better paid over time, have seen their poverty risk greatly reduced. But, on average, those who live with family members employed in agriculture as self-employed have not seen either sustainable improvement in their living standards, or a fall in the poverty risk.

\subsection{Georgian labor market in transition}

22. Georgian labor market has played a significant role in helping the population to cope with the collapse of the planned economy. Nowadays it shows impressive signs of dynamism as the economy picks up. This section first presents the overview of initial labor market conditions that prevailed at the start of transition, main trends in the labor force participation rate, employment and unemployment, sectoral composition of employment and real wage developments from 1990-97.

23. Georgian labor market under the planning system. An understanding of the labor relations framework under the Soviet system is a prerequisite to any in-depth analysis of the Georgian labor market today. Although the institutional structure has been profoundly altered by the process of first political, and later economic change that began at the end of 1980s, the Soviet legacy of a dual labor market, with heavily taxed and rigid formal market and "wildly" liberal informal economy, has influenced the labor market developments in transition. The contradiction between the new economic reality and the regulatory and labor income taxation framework inherited from the past are at the root of the increasing informalization of the Georgian labor force and weakening fiscal position of the State. On the other hand, the flexibility of an informal labor relations system has played a key role in tempering the negative impact of economic and political turmoil on living standards of the population.

\footnotetext{
4 Unfortunately the survey does not contain the information on detailed occupational positions and it is impossible to do the full decomposition of the gender wage gap. 5 Based on the regression specification similar to reported in the Annex 1, restricting sample to government employees (not reported).
} 
24. At independence, agriculture accounted for about one third of GDP, followed by industry and construction (one quarter of output jointly); therefore, these three branches accounted for over a half of total output. This reflected Soviet planning priorities, in particular, the emphasis on industrial development and neglect of services. Economic rationale of USRR also arguably resulted in a lower level of diversification in agriculture than might have been expected in a country with varied natural resources. In 1990, grape, tea and citrus tree cultivation represented the bulk of agricultural output, compared to a much lower share for grain and potatoes. The republic was heavily dependent on food imports from Russia and Ukraine, particularly grain.

25. The structure of employment preceding the independence in 1991 mirrors that of the economy, indicating the importance of agriculture which accounted for about 25 percent of total employment. Industry and construction followed, together employing about 30 percent of the total. As in other planned economies, Georgia's retail and trade services were relatively underdeveloped. The so-called non-material sphere accounted for about one third of employment, the bulk of which comprised social services, in particular, education.

26. Industrial production has been mostly State, with a small sector of independent cooperatives. Agricultural production was organized into kolhozy (collective farms) and sovkhozy (state farms) and a limited area allowed for private plots. The forms of agricultural ownership were mainly distinguished by the method of payment to workers: the sovkhozy paid fixed salaries to workers, whereas the kolkhoz paid workers out of its own residual revenue. However, employment on private plots has been a very important part of the rural economy. Official figures suggest that in 1990, a significant share of main agricultural products have been produced on private plots. Laboring private plots and traveling to urban centers (in or outside Georgia) to sell the products was a predominant form of informal employment for a substantial part of the labor force officially counted as employed in kolkhozy or sovkhzy. Crop production on the household plots of collective farm members was the main legally sanctioned private activity, and of particular importance to Georgia with its favorable soils and climate.

27. Changes in the relative share of employment by type of ownership since the mid 1980s show the increasing significance of the private sector, which accounted for about 21 percent of employment in 1992 according to officially published data. Co-operatives producing goods and services (legalized in 1987), accounted for a further 8 percent of employment. The state sector nonetheless remained dominant -- state enterprises and farms accounted for about two-thirds of employment, and collective farms for an additional 4 percent.

28. Though the private economic activity outside agriculture was strictly circumscribed by law, the informal sector in services and even in industrial production was flourishing.

Employment of hired labor was banned, for example, and input supplies were difficult to obtain through legal channels. This created a quite sophisticated system of procurement and marketing going far beyond the borders of Georgia. Most of workers in the informal sector had been formal wage employees receiving their wages, but who were additionally involved in non-reported income-generating activities, often at their formal employment workplaces. Thus, the informal sector was very heterogeneous, including the self-employed, unpaid family workers as well as those with double employment. And wages from primary formal employment were regarded as an unimportant part of the total earnings, dependent still on the status granted by formal sector job. 
29. Unemployment was supposed to have been "eliminated completely" in the Soviet Union in 1930, yet this official stance was increasingly recognized as untenable in the 1980s, even if unemployment statistics did not exist. The Soviet labor market was characterized by substantial regional disparities. Georgia has been classified as a region of "excess labor supply" where the number of working age population exceeded the number of jobs in the official economy (Marnie 1992). This was in contrast to the western regions of the former Soviet Union which had been affected by "labor shortages". An estimated 10 percent of working age adults in Georgia had not been provided with jobs in the official economy in 1989. However, this number would also include voluntary non-participation, making the estimates of "disguised unemployment" relatively low.

30. Soviet wages were set centrally so that the structure of wage relativities under the tariff system in Georgia was similar to that in Russia. Construction and industrial workers were relatively better paid, whereas those working in agriculture received below average wages.

Average wages in the service sector (education, health, housing, and culture), were even less than wages in agriculture. During the late Soviet period, there were shifts in the relative position of workers in different branches of the economy were towards a relative improvement in the position of agricultural workers and partial loss of relatively privileged position by industrial workers. At the same time, among workers in the social sectors (health, social security, education and culture), there was greater stability.

31. Labor legislation tightly regulated the labor market; labor unions were integrated into public administration and played a role of enforcement mechanisms. Legislation offered quite generous sickness, retraining and disability insurance, and various other benefits which included housing and subsidized meals. Legislation also worked towards compressing wage differentials by education and gender. The tax regime had been based on the payroll in State enterprises and kolkhozy for calculating main social security contributions. The income tax was levied at the source, and most employees were already receiving net wages, with all deductions made.

\section{Impact of transition: changes in participation}

32. The typically high participation rate for a socialist economy ( 89 percent of the population in working age in 1989), had prevailed in Georgia before the transition started. It is widely believed that this participation rate has been artificially high for a number of institutional reasons. The average participation rate for the population of working age (according to the pretransition definition), observed in 1997 was around 70 per cent. ${ }^{6}$ Therefore, a large drop in participation of about 20 percentage points had occurred over transition. This fall of such magnitude is much higher than observed in Russia, but in line with other transition economies that went trough a profound collapse of output (Armenia being the closest comparator).

6 Around 20 per cent of men in working age are economically inactive, and around 35 per cent for women. SDS household survey, for ages 16-54 for females, 16-59 for males; participation rate pre-transition was all employed including those employed in the formal economy or registered as employed on their own account minus employed outside the working age to the working age population. LFS definition includes not only employed, but also the unemployed in the labor force. 
Figure 3.

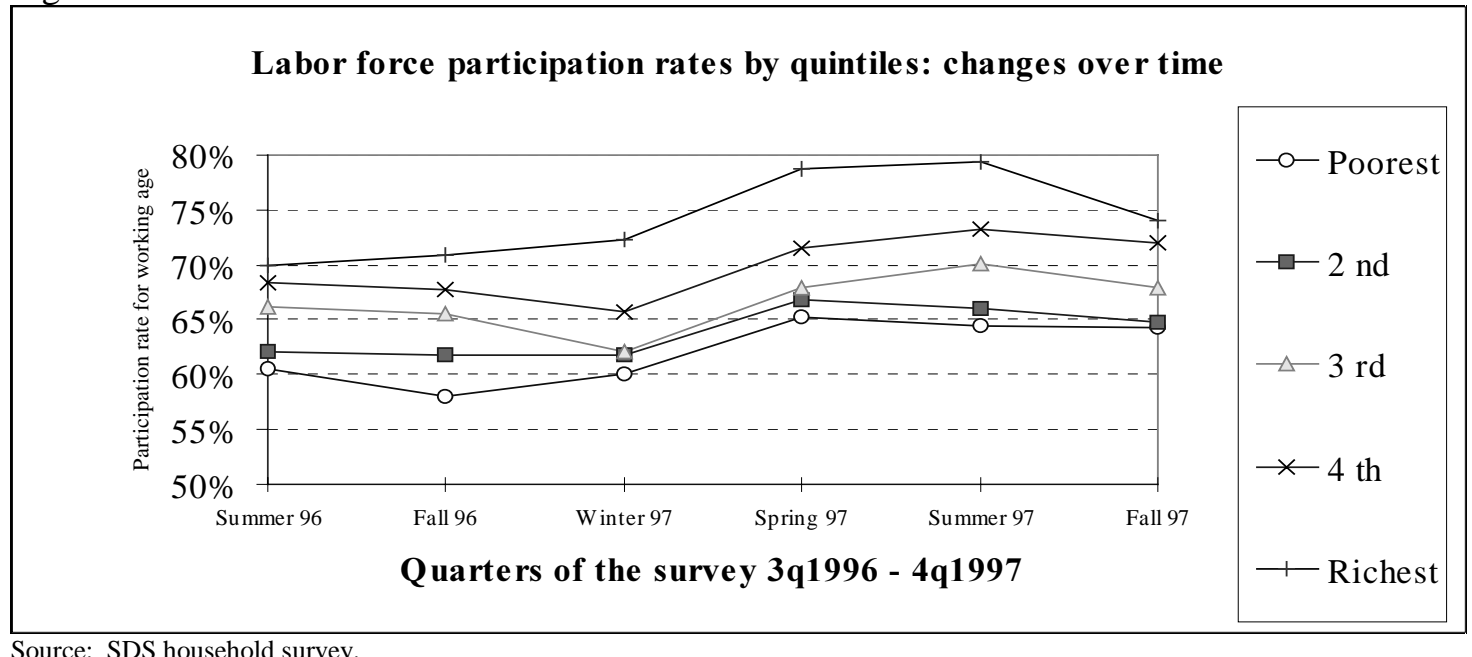

33. Since the economy started to grow there has been a rise in the participation. This rise is remarkably uniform across the consumption classes (see Figure 3), and across regions as well, but not uniform for urban versus rural areas (see Section 2.3).

\section{Changes in employment and unemployment}

34. At first glance, Georgia seems to share a common asymmetry, for example with Russia, that characterizes the response of employment to output contraction in FSU countries. This is quite evident at an aggregate level from Figure 4 in which cumulative changes to employment at end-1997 compared to 1990 can be seen to have greatly lagged those changes to output. This Figure, however, is based on aggregate numbers, and these are seriously misleading in a number of key respects (as we show below), mainly because there was a substantial labor reallocation between sectors. But this tells only one part of the story. While net job destruction has been very restrained, leading to large falls in labor productivity, adjustment in hours has been significant, weakening the productivity decline (when factoring in time). Adjustments through hours have also been significant; in the middle of 1996 about 20 percent of all wage employees had an average work week of less than 15 hours. However, it is important to note that the shock to employment has been much less pronounced than the output drop.

35. The aggregate picture presented by official statistics where adjustments in employment appear to have lagged behind the declines in output, may well fail to reveal the extent of adjustment on the price side of the labor market. One possible explanation of hoarding labor is that there has been extreme wage flexibility. At the end of 1995, average real wages had, according to SDS, fallen to around one tenth of the level observed before transition began. An additional price adjustment mechanism used by enterprises to counter output shocks was the delay of wage payments to workers. As the SDS survey has shown, by 1997 wage arrears affected no less than 5 percent of wage employees at any point in time. 
Figure 4.

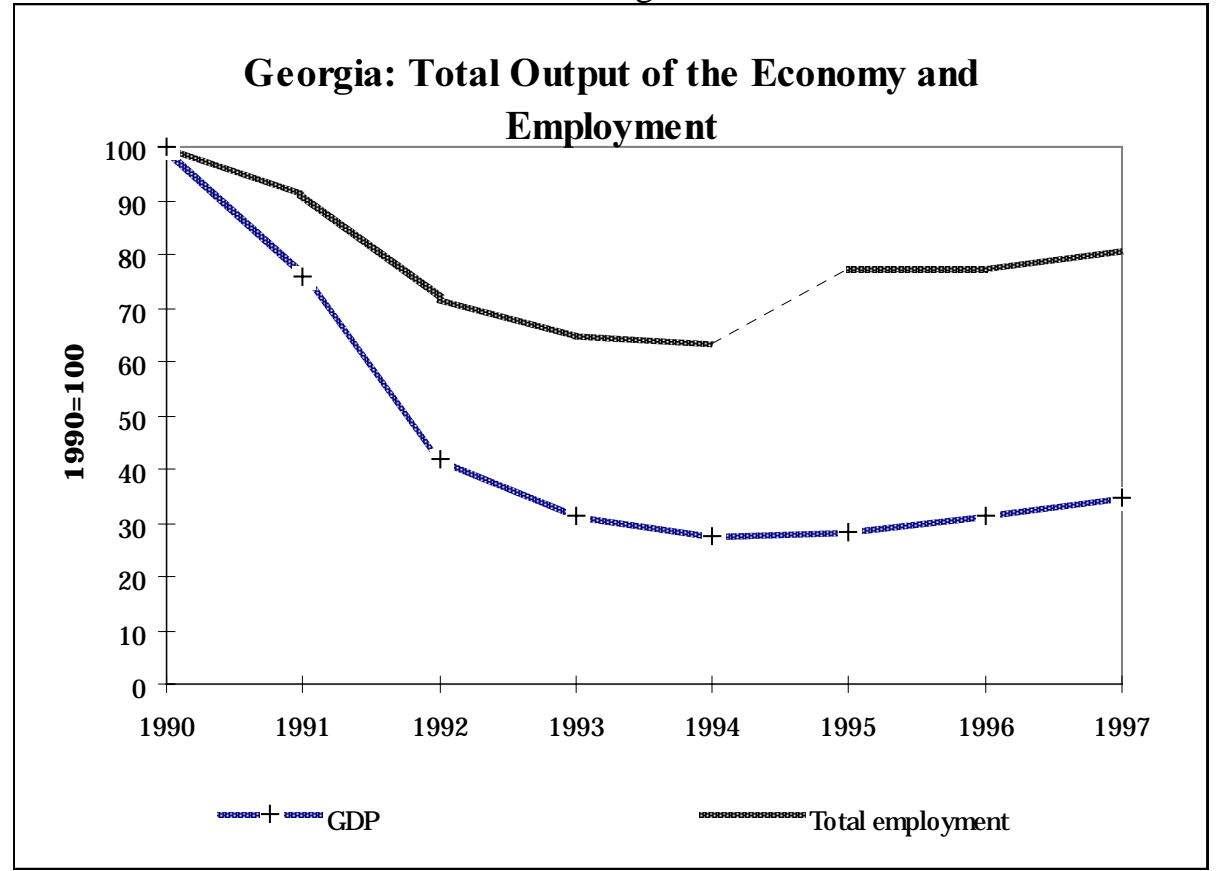

Source: IMF; SDS data on employment before 1992.

Note: Series of employment show a break in 1995 because of changing methodology, as estimates of the informal selfemployment were included into the total employment figures. Since 1996 these estimates are based on household survey.

36. As the output per worker has collapsed, real wages plummeted, but the brunt of the adjustment has been concentrated in specific sectors. The allocation of losses to employment in Georgia was very unequal between sectors of the economy. ${ }^{7}$ Aggregates disguise considerable heterogeneity, as sectors rise and fall consistent with restructuring, and hence the distribution consequences are far from obvious.

37. By the end of 1997, Industrial employment, though initially showing strong signs of labor shedding, by the end of the 1997 almost matched in its fall the reduction of output (see Figure 5, panel b). This was achieved by continuing cuts to employment by large- and mediumsized industrial firms. The industrial sector has been reduced to very basic functions; a quarter of the value of its output is electricity generation, and 15 percent is bread baking.

38. The overall drop in employment was dampened by a remarkable stability of employment in agriculture, even in the worst years of the crisis, and a rapid expansion afterwards (Figure 5 panel a). By the end of 1997, the employment in agriculture had doubled compared to its level in 1990. This expansion is partly due to statistical factors, but the stability of employment in the first years of transition when statistical practices were kept unchanged shows a compelling story of labor hoarding. Yet the underlying institutional structure supporting this labor hoarding was quite different from factors responsible for hoarding labor in the Russian economy.

\footnotetext{
7 In contrast to Russia, almost uniformly, instead of shedding employment, involuntary leave of absence, reduction of hours and wage arrears were the alternative means by which firms have adjusted to contraction in sales for their goods and rising liquidity constraints. Therefore, while aggregate employment levels may have remained high, these tools of labor market adjustment could have rendered employment less secure and less remunerative quite uniformly for many labor market participants.
} 
Figure 5.
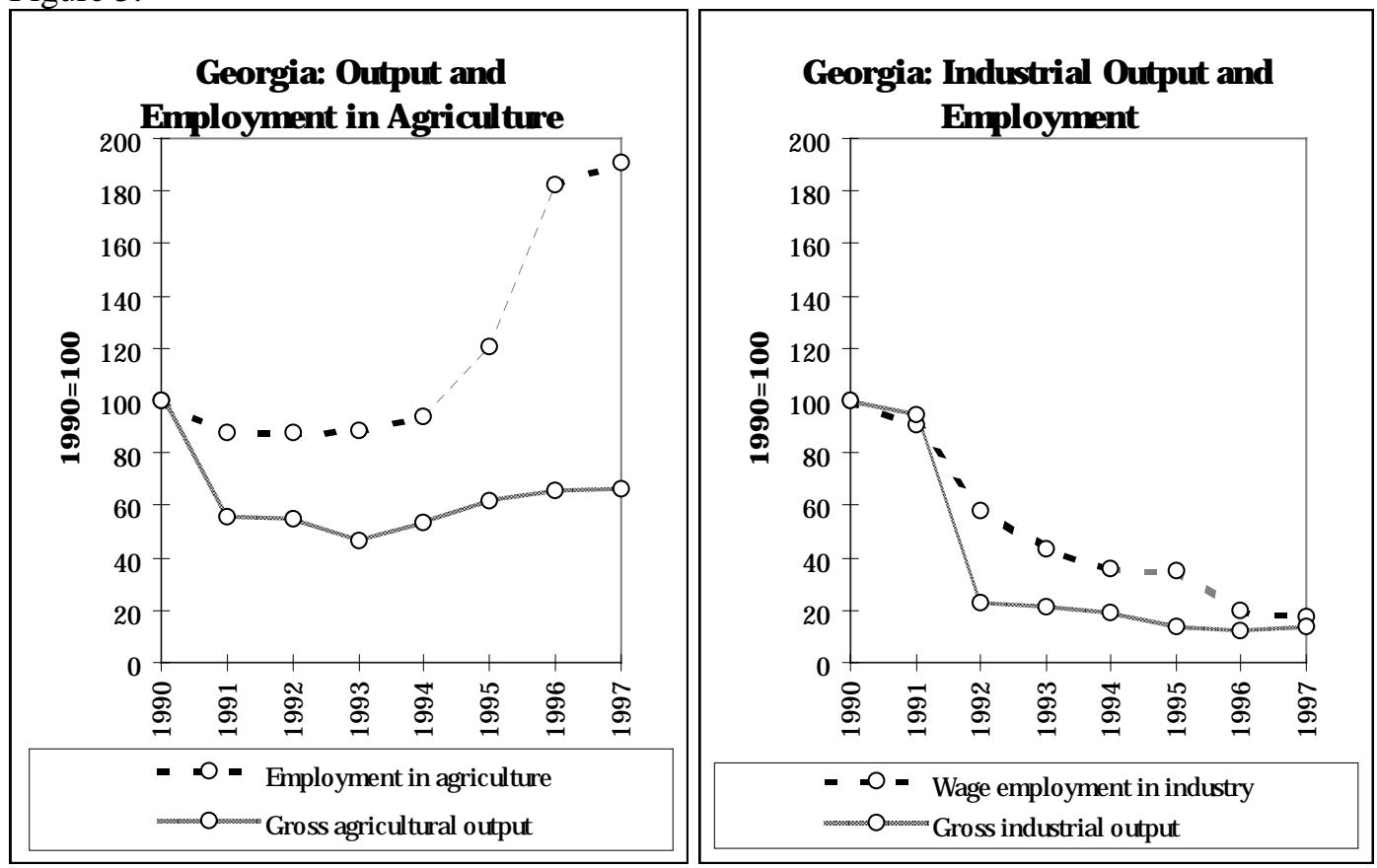

a)

b)

Source: SDS official data on gross output and employment.

39. Rather than preserving employment at the existing large agricultural enterprises, Georgian agriculture underwent a profound change in the ownership structure. With the privatization of land to rural population, the dominant form of agricultural production had become private $0.5-1$ hectare plots. At the same time, there was a significant reduction in the use of fertilizers, tractors and other capital equipment due to a breakdown of industry and trade links to other FSU countries. This reduced the productivity of agricultural workers. By 1997, the value added per worker in agriculture hardly exceeded 100 lari/month; four times lower than in trade and five times less than in industry and construction.

40. Table 2 uses the SDS household survey to follow closely the sectoral growth rates of employment, matching them to changes in output over one year. Overall, the GDP growth and the change in total employment have been very similar, about 10 percent. But the decomposition of growth by branches shows huge disparities consistent with the economic factors that were responsible for hoarding labor. Agriculture is the dominant employer, but also the sector where most of the employment between 1996 and 1997 has been created. As we have noted earlier, a substantial part of this growth has been the rise of self-employment, and within self-employment, is the increase in the number of unpaid family workers. On the other hand, industrial employment continues to fall -- not a surprising fact given the remaining labor hoarding. The expansion of trade and transport has been more or less in line with economic development. 
Table 2: Employment growth and output by branches of economy in 1996-97

\begin{tabular}{|lccc|}
\hline & $\begin{array}{c}\text { GDP growth between } \\
1996 \text { and 1997 } \\
\text { (percent) }\end{array}$ & $\begin{array}{c}\text { Employment } \\
\text { growth 1996-97 } \\
\text { (percent) }\end{array}$ & $\begin{array}{c}\text { Total employment } \\
\text { in 1997 } \\
\text { (thousand) }\end{array}$ \\
\hline Agriculture & & & \\
Industry & 2 & 16 & 1,210 \\
Construction & 17 & -11 & 126 \\
Transport and communications & 2 & -3 & 41 \\
Trade and catering & 37 & 11 & 88 \\
Other & 13 & 15 & 285 \\
Total & 29 & 0 & 482 \\
\hline
\end{tabular}

Source: Official SDS publication, SDS household survey for employment by branch

Note: GDP is at factor costs.

41. Behind the changes in sectoral employment there has been a continuing reallocation of labor between different types of employment. A look at Table 3 brings up an important issue for the type of adjustment that we observe on the Georgian labor market: most of labor creation is concentrated in self-employment. In fact, wage employment between 1996 and 1997 has fallen both in absolute levels and as a share of total employment. This development reflects the trend towards growing informalization of the labor market observed over the last decade, but it underscores the fragility of social insurance arrangements prevailing in Georgia.

Table 3. Employment by type of employment 1996-97

\begin{tabular}{|l|ccc|}
\hline & $\begin{array}{c}\text { Employment in } \\
1996 \text { (thousand) }\end{array}$ & $\begin{array}{c}\text { Employment in } \\
1997 \text { (thousand) }\end{array}$ & Change (thousand) \\
\hline Wage employment & 711 & 704 & -7 \\
$\quad$ State sector & 580 & 569 & -11 \\
Cooperatives & 55 & 47 & -8 \\
Private firms & 76 & 88 & +12 \\
Self-employment & 1,324 & 1,529 & +205 \\
Total & $\mathbf{2 , 0 3 6}$ & $\mathbf{2 , 2 3 3}$ & $+\mathbf{1 9 7}$ \\
\hline
\end{tabular}

42. As a result of relative sluggishness in the contraction of employment, the unemployment is relatively low as the employment losses seem to have been less dramatic than one would expect given the scale of output contraction. As can be seen in Figure 4, employment has fallen only by 20 percent between 1990 and 1997 and unemployment, as suggested by official data on registered jobseekers, has fluctuated during this period between 2.5 and 11 percent of the labor force.

43. Figure 6 depicts trends in the number of registered unemployed. These seem to bear no relation to the overall economic trends, but rather lag changes in the regime of granting benefits and the level of unemployment allowances. These, however, are still low (on average, 30 percent of the average wage in national economy for 1996, and by end 1997 about 20 percent), and paid for a short period of time ( 6 months before 1998, 12 months now). Thus the incentives to register and to re-register are low. The rise in the number of registered unemployed in 1997 could be attributed to the eligibility of families with registered unemployed to family allowances, soon abandoned. Thus, there has been almost three-times the increase in the number of registered jobseekers between June and September of 1997 without any significant effect on the 
labor market except announcement of eligibility rules for family allowances. Registered unemployment started to fall when the list of beneficiaries for family allowances narrowed, excluding the unemployed. An increase in the level of unemployment benefits from 8.5 lari to 13 lari, and the extension of the duration of benefits has attenuated this outflow. Thus the registered unemployment offers a very misleading picture of the labor market.

Figure 6.

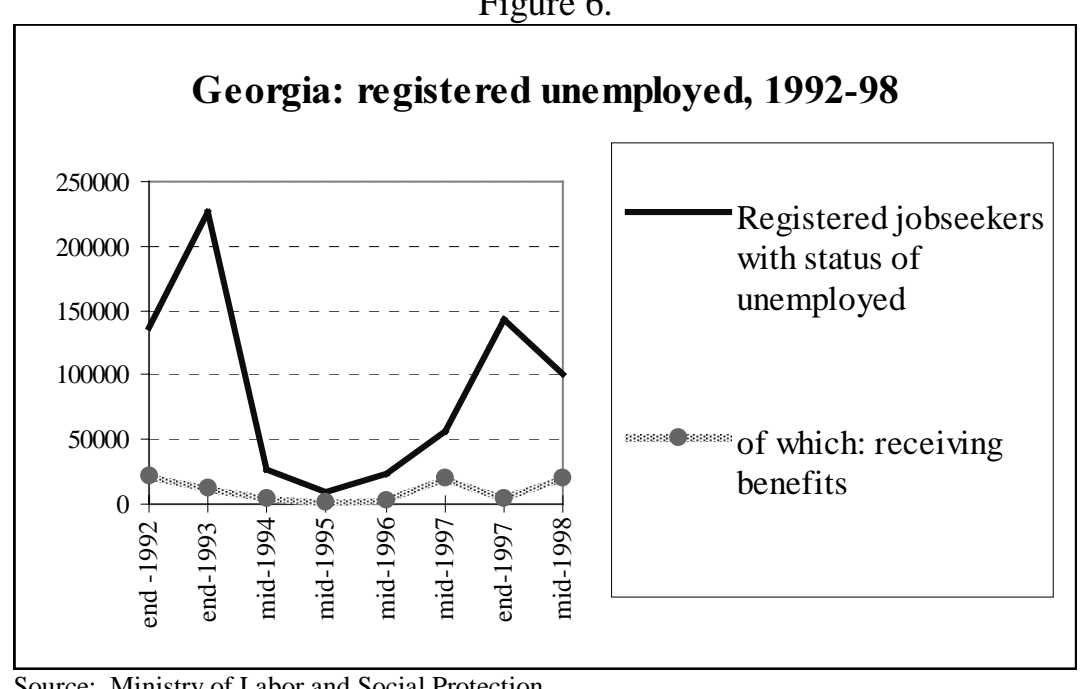

44. The operation of formal labor job matching is further restrained by insider dominance at the Georgian firms, and an unwillingness to post any vacancies. The number of vacancies posted at the labor offices never exceeded 1500 for the country as a whole, and the outflow from registering for jobs has been minimal. The survey of industrial companies conducted by SDS in 1997 in main urban centers has found that only 11 percent of the 400 firms surveyed provided information on vacancies and layoffs to the employment service, and almost exclusively on ad hoc irregular basis. ${ }^{8}$

45. Therefore, the only reliable source of information on the labor market in Georgia is from the nation-wide household survey. By mid-1996, the time of the first labor forces survey (SDS household survey has included a standard LFS attachment), the total unemployment stood at 12.8 percent of the labor force, as defined by ILO/OECD criteria to include those without work, available for work and actively looking for work, but not necessarily registered with the State Employment Service. Figure 7 shows that the unemployment rate has fallen since mid 1996 from almost 13 to less than 5 percent of labor force. Using the "soft" definition of unemployment (which discouraged inactive job seekers), the progress is similarly impressive, dropping from 20 percent to 8 percent of the labor force.

46. Unemployment is becoming a phenomenon that affects very specific groups of the population. New entrants at the labor market, (young people below the age of 25) have an unemployment rate that is twice the population average. Unemployment is also more prevalent among women than among men. Finally, there are striking differences in the level and dynamics of unemployment between urban and rural areas and between regions that we will analyze in Sections 2.3 and 2.4.

8 Georgian economic trends, 3rd quarter, 1997, p.50. 
Figure 7.

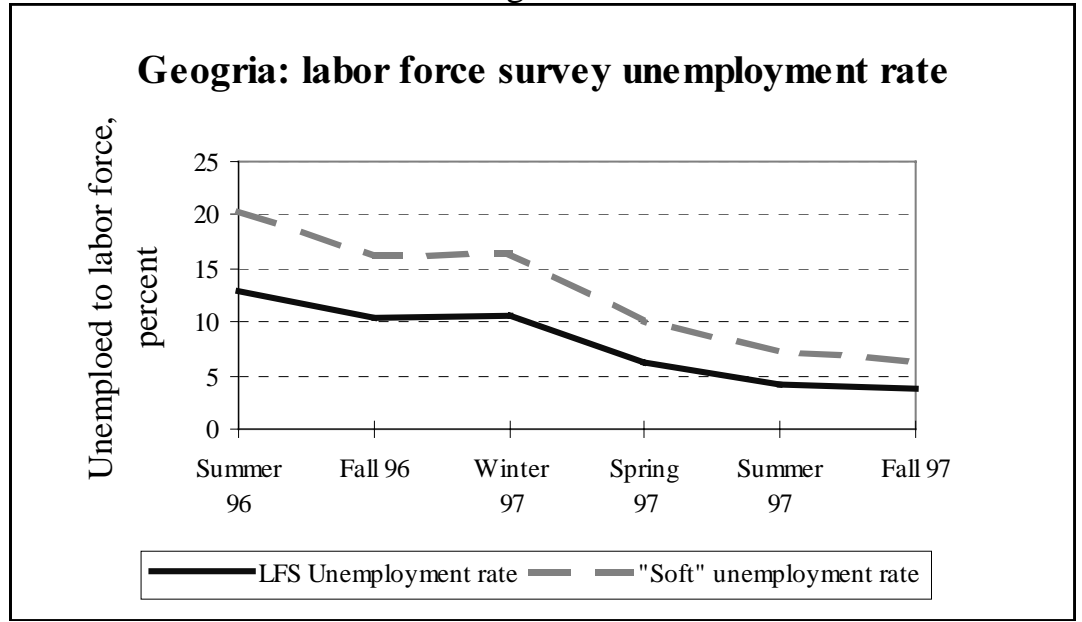

Source: Georgian economic trends, various issues; since the SDS survey does not cover refugees settled in "organized way", many of whom are registered as unemployed, the unemployment numbers based on the survey cannot be compared to registration statistics.

\section{$\underline{\text { Real wage developments }}$}

47. In general, labor market adjustment in the former Soviet Union has taken place on the wage (price) side. Given the overall fall of employment relative to the fall of output in Georgia during the years of transition, the fall of earnings has been extremely deep.

Figure 8.

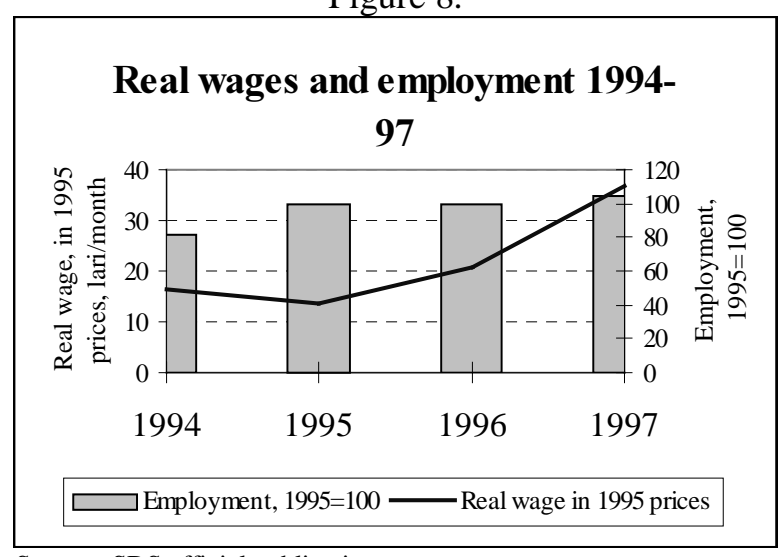

Source: SDS official publications.

48. The resumption of growth since 1995 was occurred on the environment of labor hoarding with enormous employment slack. Thus, the economic expansion has operated through growing utilization of labor and rising wages, but not necessarily through sustained employment growth. Unfortunately, official data is too fragmentary to tell a consistent story of how the economic recovery has impacted on employment. As Figure 8 shows, the real wage has doubled over 1994-97. The expansion of employment, as one would expect given the degree of labor hoarding, was much less rapid. 
49. There are significant differences in wages between the different sectors (State, privatized and private firms) of the economy. Private wages by their nature are more difficult to capture. The secondary or parallel nature of many of these jobs further complicates any comparison. Using the SDS household survey responses, we can nevertheless build a coherent picture. Figure 9 summarizes the available information on relative wages and indicates significant monetary wage premia being offered by privatized and private firms. While using regression that controls for differences in workers' endowments between sectors, we observe that private firms are paying a premium of 20 percent over the government sector, SOE and privatized sector wages. But also, it is quite characteristic that take-home wage incomes have been fairly volatile in all sectors, driven by changing incidence of arrears in the State sector, and arbitrage and episodic windfall rents, with an emphasis on maximizing short run returns in the private sector.

Figure 9.

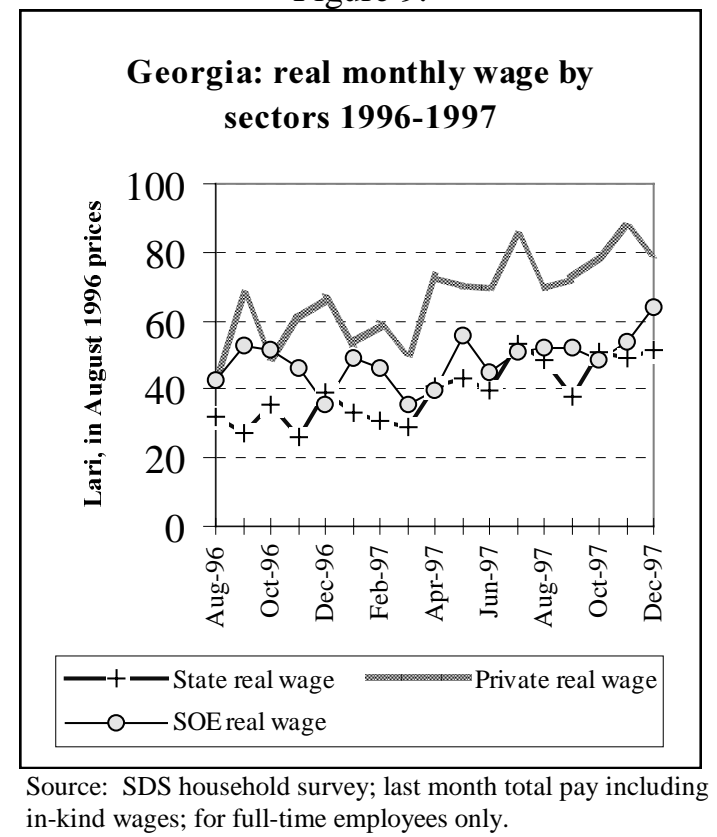

\section{$\underline{\text { Regulatory framework and taxation }}$}

50. The labor relations in the State sector are still regulated by old norms. But since it has shrunk in size considerably, and the value of many discretionary benefits (like free of charge kindergartens maintained by employers, or subsidized canteens) or mandatory benefits (sickness benefit) has been eroded by a liquidity squeeze, the current distortionary impact of these is minimal. The whole array of mandated benefits and labor norms inherited from the Soviet regime is now of little relevance to the private sector employers. There are reports of violations of employees' basic rights, and State agencies are among the worst abusers. A simple fact of wage arrears by itself is at odds with obeying the law. Rising insecurity of employment and gender discrimination through denial of maternity benefits is the downside of flexibility observed at the labor market. As the costs for the society of no labor protection starts to overweigh the benefits of a freely operating labor market, the Government gradually introduces norms and legislation which regulates the main aspects of labor relations, and grants workers basic accident and sickness insurance and maternity benefits regardless of the sector of employment. 
51. Minimum wage is a potentially strong device to alter the operations of the labor market. In Georgia the minimum wage is fixed by Law and used as the basic wage for compensation in the State sector. Due to its low level (not exceeding 20 percent of the average wage in the economy at any point in time in 1994-97), the minimum wage is not acting as a binding constraint on the labor market. However, the existing Law on the minimum subsistence realistically does not require raising the minimum wage to the subsistence minimum, but rather indexing it at the current fraction of poverty line.

52. Where the distortionary effects of State interventions on the labor market are much greater, is in the current taxation regime. The business community often complains about the burden of the payroll taxes, the level of which is actually higher in Georgia than in many industrialized countries, and which has by far more sophisticated tax authorities. The measure of tax burden is tax wedge - the total cost to the employer of the net salary received by the employee. For Georgia, the tax wedge for a gross monthly salary of 200 lari is 1.66 , thus increasing the cost of labor by at least 66 percent. ${ }^{9}$ For comparison, in the United Kingdom the tax wedge for a monthly salary of 1000 pounds is 1.27 in the worst case, i.e., excluding all possible deductions and allowances, almost nonexistent in Georgia. The pension fund contributions alone ( 27 percent of gross wage for the employer and 1 percent for the employee), is a heavy burden on many enterprises and no doubt encourages evasion, resulting in a shrinking tax base and imposing a heavy claim on the general budget revenues.

53. In Georgia's case, regulations hurt the poor to the extent that regulations create a wedge between the workers' take-home income and employer's costs, and increase the incentives to move to the informal sector. The positive outcome of such regulations -- legal protection, reduced discrimination against weaker workers, i.e., women, non-discretionary benefits, social security, training opportunities, some job stability, -- has yet to be imposed (enforced), and therefore do not act as formal sector attraction.

54. Conclusion to section 2.2: The Georgian labor market has shown an outstanding resilience to economic shocks of transition. It has largely been granted by the absorption of workers released from the State sector by non-participation and self-employment.

Unemployment was low and is falling with economic growth. However, considerable labor hoarding remains in many sectors of the economy. The growth therefore has impacted upon increasing incomes of workers that are still employed in the formal sector, rather than raising the numbers of employed for wage. An obvious obstacle to raising wage employment is the high tax burden on formal sector labor earnings. There are substantial differences in labor market performance between economic sectors and regions of the country, as we are now going to see.

\subsection{Urban labor markets}

55. The population of Georgia is predominantly urban. Georgia has a number of large cities and high diversity of urban economies ranging from major ports and industrial centers to landlocked small towns primarily serving nearby rural neighborhoods. The response to the crisis of urban labor markets has been extremely diverse too, but one main common trend exists: increasing employment with stable participation. The rise in employment operated mainly through expansion of self-employment activities leading to falling unemployment and rising earnings.

9 Despite the low income tax, culminating at 20 percent, there are many social funds contributions, such as pensions, social insurance, medical insurance and employment insurance raised as payroll taxes. The further discussion in this paragraph is based on the information reported in Georgian Economic Trends. 
56. Labor market participation. Most of the adjustment that was observed in Georgia on the side of the labor supply had occurred in urban areas. The labor force participation rate in the SDS household survey for urban dwellers is a full 15 percentage points below the one observed in rural areas. In addition, it does not show any upward trend, which is the case in rural areas.

57. Urban women are particularly prone to drop out of the labor force as the transition began. In fact, according to the SDS survey, the participation rate for urban females of working age ${ }^{10}$ has been only 52 percent, as opposed to 73 percent for working age females in rural areas. The gap of similar proportions exists when we narrow the definition of working age to the 25-55 age range. The participation rate of females in urban areas is particularly low between ages 20 and 35, suggesting that one of the leading causes of females dropping out of the labor force in urban areas might be the unavailability of child care and household responsibilities assumed by women in extended households. With other personal and household characteristics held constant ${ }^{11}$, the number of children below the age of 7 and the number of elderly in a household are significant factors reducing the probability of urban females contributing to the labor force.

58. Migration from rural to urban areas has played an important role in the growth of Georgian cities in the past. Today the uncertainty of employment opportunities in cities, the lack of remunerative work, and the presence of a large number of refugees in many large Georgian cities "congesting" the labor market, have put these flows to a halt. As the SDS household survey indicates, of all urban residents, roughly 3 percent are recent migrants who came to cities in the last 5 years. This matches almost exactly the number of refugees who have settled in an "unorganized" way, i.e., integrated in the families.

Figure 10.

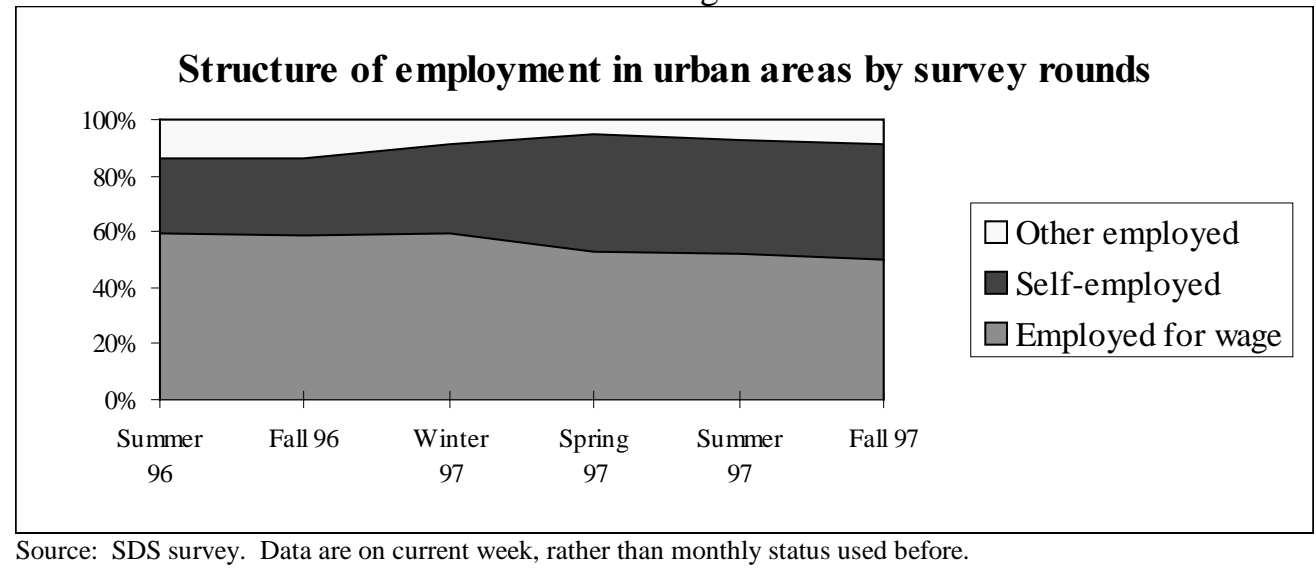

59. Structure of employment in urban areas. Changes in the employment structure in urban areas (Figure 10) point out the growing informalization of employment.

60. The employment in private firms in urban areas has expanded by almost a third in just one year, but this growth did not compensate for the fall in the employment by the Government, SOE and privatized companies. Cuts in employment have been concentrated in education,

10 Working age defined as 14 and above

11 Result is obtained with probit regression relating the participation of women in prime working age to their age, education, region, household composition, and income of household head restricting sample to spouses of household heads - not reported, available on request. 
electricity, gas and water supply. But total wage employment was stagnant, while selfemployment was growing over the period. By the end of 1997, less than half of total urban employment had been on a payroll of any kind.

61. A substantial part of growth in self-employment is in fact a result of different labor market arrangements to evade taxation. When we decompose the urban self-employment by branches, we find that the second largest and the most rapidly growing area of self-employment (after agriculture) is trade. Trade employs around 40 percent of all self-employed in urban areas (counting only those who mark self-employment as primary occupation). Some of its expansion in fact represents subcontracting by large wholesalers who economize this way on various costs ${ }^{12}$ (including labor). Together, trade, agriculture and transportation cover 90 percent of all selfemployment in urban areas.

62. In addition to those who have self-employment as a sole and primary occupation, 20 percent of wage employees have to supplement their meager wages with some kind of selfemployment. In an absolute majority of cases this is subsistence gardening. There is no tendency over the period of observation for the reduction of this share.

63. The most dynamic part of the industrial sector -- small, usually de nuovo private firms is still only a minor actor in the urban labor markets. Unfortunately the SDS household survey does not contain any information on the size of firms where respondents were employed. But aggregate numbers on output witness that small industrial companies (with less than 20 employees), contribute only about 7 percent to the total industrial output of Georgia (SDS halfyear report). The lack of clear legal framework, and limited opportunities to raise start-up capital are the main impediments for growth of these enterprises (Dudwick, p. 35).

64. The growth of urban employment has been fairly heterogeneous across regions (Figure 11). The total employment has grown most in Imereti, but even at that rate of expansion, it has achieved only the level of Tbilisi, which was low and seems rather stagnant. There has been some conversion at the highest end of the spectrum, with Adjara, Samtskhe Javakheti and Kakheti at the highest employment rate. The remarkable achievement in some regions needs qualification; almost all of employment growth was due to expansion of agricultural selfemployment in urban areas. In Imerety, by the end of 1997 agricultural self-employment accounted for 60 percent of all urban employment; in Guria and Kakheti it accounted for 55 percent. Self-employment in non-agricultural activities is particularly prevalent in Tbilisi (close to 30 percent of all employed) and in Samegrelo (33 percent). The lowest rate is observed in Guria, where there was less than 10 percent urban employment by the end of 1997 . Nowhere private firms wage employment is the leading form of occupation for urban population, but their shares are highest in Tbilisi (15 percent of all employed), closely followed by Adjara and Samegrelo. The government is still the main urban employer in Tbilisi (about a third of all employees), in Qvemo Kartli and in Samtskhe Javakheti.

12 As noticed, for example in Dudwick (1997), pp.31-34. 
Figure 11.

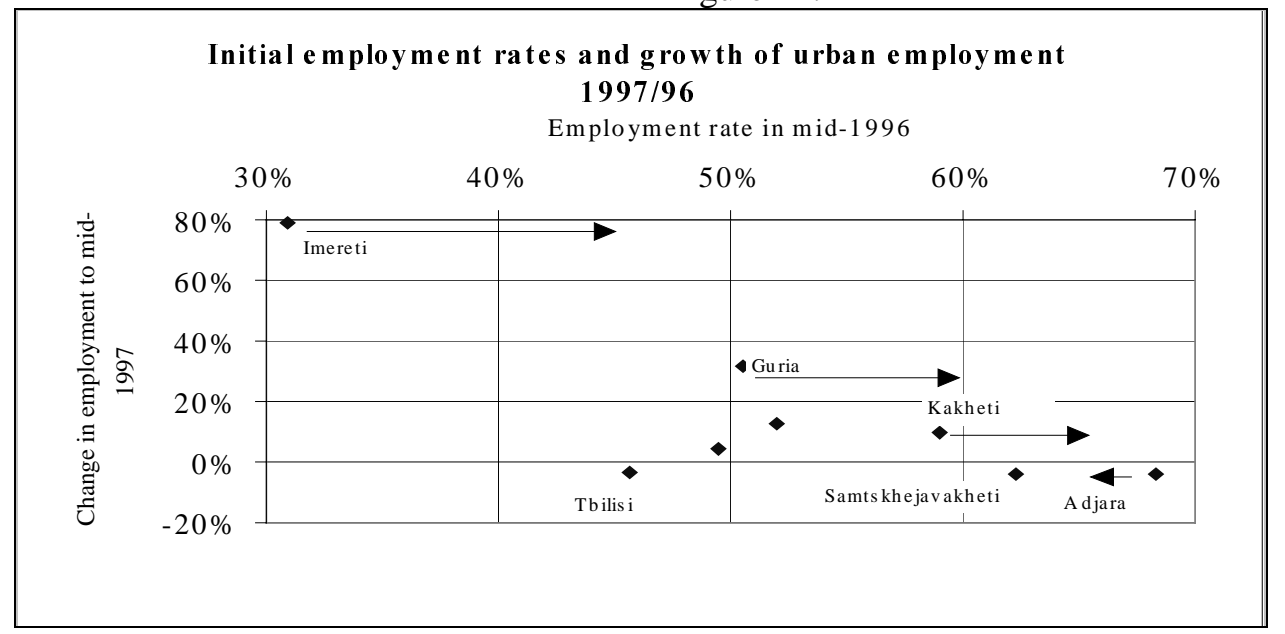

Source: SDS household survey; employment rates share of all employed in the working age population (over 14 years old), arrows mark the final position of the region with respect to the employment rate.

65. Unemployment. A good indicator of local urban labor markets performance is the unemployment rate. Here the emerging picture mirrors closely the progress in employment generation in urban areas. Table 4 highlights the differences in regional unemployment rates and different pace of their reduction. Tbilisi features prominently as the city with the highest and the most stubborn unemployment rate. The initial level of unemployment in Imereti is very high and explains also the high incidence of poverty observed for this region (see Chapter 2).

66. Initial conditions appear to be a crucial determinant of regional urban labor market performance. This dispersion in regional unemployment rates is hardly surprising, after all different regions have received different magnitudes of shocks. The prevalence of large industrial and mining enterprises in Imereti and heavy industry in Tbilisi and Shida Kartli explains the sustained high unemployment levels. An over-reliance of urban industrial sector in Guria on processing tea also explains its relatively poor achievements, with tea production being heavily hit by the crisis. What is more interesting -- and obviously more difficult -- is to understand how divergent regional unemployment will remain and for how long.

Table 4. Urban unemployment rate by regions (percent to labor force)

\begin{tabular}{|lrrrrrr|}
\hline \multicolumn{1}{r}{ Summer 96 } & Fall 96 & Winter 97 & Spring 97 & Summer 97 & Fall 97 \\
\hline Kakheti & 9 & 4 & 3 & 3 & 3 & 1 \\
Tbilisi & 23 & 17 & 19 & 21 & 16 & 15 \\
Shida kartli & 16 & 11 & 9 & 10 & 9 & 9 \\
Qvemo kartli & 15 & 11 & 8 & 9 & 7 & 5 \\
Samtskhe-javakheti & 1 & 13 & 11 & 3 & 2 & 1 \\
Adjara & 4 & 4 & 4 & 2 & 2 & 2 \\
Guria & 27 & 16 & 9 & 3 & 3 & 10 \\
Samegrelo & 12 & 14 & 10 & 7 & 6 & 6 \\
Imereti & 41 & 38 & 28 & 20 & 19 & 9 \\
& & & & & & $\mathbf{1 2}$ \\
Total urban areas & $\mathbf{2 2}$ & $\mathbf{1 7}$ & $\mathbf{1 6}$ & $\mathbf{1 5}$ & $\mathbf{1 0}$ \\
\hline
\end{tabular}

Source: SDS household survey. As the additional cleaning of primary records has been undertaken to remove double counting in some cases, the numbers may slightly differ from official publications by SDS. 
67. Putting together aggregate numbers on employment, we find that most of the unemployment reduction in urban areas has been absorbed by expansion of self-employment, primarily (and quite paradoxically) in agriculture. Self-employment is by now so dominant, that it is difficult to expect its further equally rapid growth. Formal private sector growth just absorbs workers released by the Government and SOE. In that situation, prospects for further improvement in the living standards of the population depend crucially on the achievements in stimulating small business development.

\section{$2.4 \quad$ Productivity of rural employment}

68. How has the population sustained the collapse of most of the modern economy in the worst crisis years? The basic movement that granted the survival of many was the "back to land" movement in a strict sense, or through family ties with relatives in villages. The rural economy has proven its capacity to absorb a huge inflow of labor released from other sectors. And now it is playing a dynamic role in the economic recovery of the country. There is practically no unemployment in rural areas and high employment rate. The achievements in the rural economy were granted by almost universal access of rural population to land. However, rural labor market shows the occurrence of failures that require public action. Thus, the main cause of rural poverty is low productivity of agricultural employment and very limited opportunities for off-farm activities. This section reviews the available evidence on the structure of rural economy and identifies areas where the Government can play a role in fostering the sustainable economic development in rural areas.

69. The structure of employment and earnings in rural areas reflects the role of agriculture as the bedrock of Georgian economy today. Agriculture provides for over 90 percent of all selfemployment and 20 percent of wage employment in rural areas, and the trend over the recent period was that of expansion (Figure 12).

Figure 12.

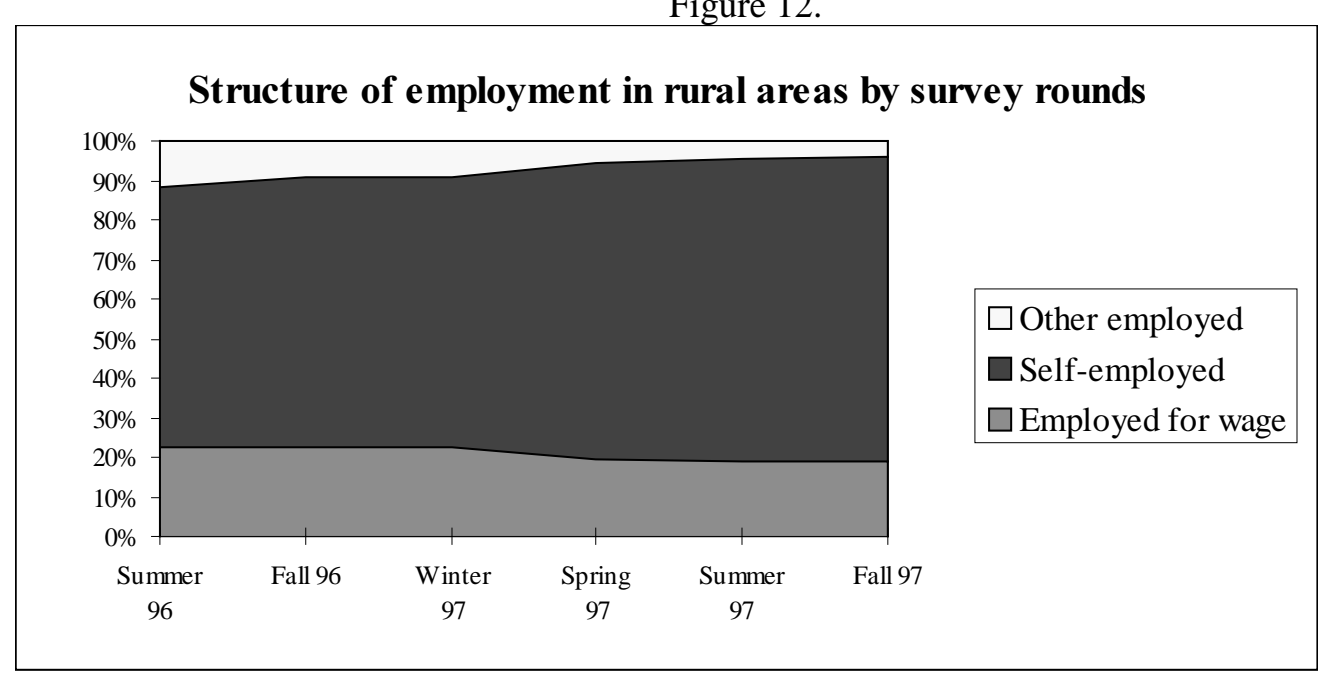

Source: SDS survey. Data are on current week, rather than monthly status used before. 
70. The picture of rising employment and practically zero unemployment in rural areas has to be qualified with a closer look on earnings from self-employment. These on average have been practically stagnant, if not falling over the period of observation (1996-97), despite the record grain harvest and overall positive weather conditions. ${ }^{13}$ This represents a sharp contrast to the rise in average wage and in off-farm earnings from self-employment.

71. There are large discrepancies in the productivity of agricultural self-employment across regions that are very closely linked to the regional incidence of poverty. Thus, the lowest average earnings per self-employed in agriculture are observed in rural Adjara (slightly more than half of the national average) which has the highest prevalence of poverty in rural areas. On the other hand, in Shida kartli which has one of the lowest risks of rural poverty in Georgia, higher than average and growing earnings are observed.

72. Rural off-farm employment in Georgia plays only a limited role in supplementing the agricultural income. Instead, in Georgia over 60 percent of all off-farm employees in rural areas have to add to their wage income from home gardening. The main off-farm activities in the rural economy of Georgia are not highly lucrative. The main employers are education (with 25 percent of all off-farm wage employment in rural areas), trade, health care and public administration. But even Government employees in rural areas rely on secondary occupations at their land plots to provide for food.

73. Off-farm self-employment in rural areas is not highly remunerative either. The average earnings from these activities (mainly petty trade), are barely higher than average agricultural incomes.

74. But even low off-farm earnings may play a crucial role in lifting households out of poverty. While only 22 percent of poor rural households in Georgia receive any wages, as much as 33 percent of non-poor households supplement their farming with wage earnings. It is also remarkable that the higher share and higher incomes from self-employment on off-farm activities in rural areas are observed in the areas with the lowest rural poverty incidence. For example, in Samegrelo, while the earnings from agriculture are well below the national average, the earnings from non-agricultural activities are 50 percent higher than on average, contributing greatly to the fact that this region has the lowest incidence of rural poverty. On the contrary, Imereti has the lowest level of earnings per self-employed in off-farm activities, despite being close to the national average in earnings from agriculture fares amongst the regions most affected by rural poverty.

75. Industrial and modern service sectors are still largely unrecovered in rural Georgia. However, potentially off-farm activities can contribute greatly to improved agricultural productivity through, for example, the manufacture of agricultural inputs, and at the same time, rising agricultural incomes can stimulate the expansion of off-farm activities, particularly in services. The off-farm sector in fast developing countries has been a key to determining the pace and direction of change in rural living standards. Studies of poverty in developing countries have discovered that off-farm employment has great potential to become a road out of poverty for many rural poor in Georgia. Nearly one-third of China's GDP is calculated to come from village enterprises. As a possible route out of poverty, off-farm employment is still largely unexplored in rural Georgia.

13 We use an all-inclusive measure of earnings: farm income per se plus in-kind consumption of own agricultural product per each person whose main occupation is selfemployment in agriculture. In the summer of 1996 , these averaged to 70 lari, while one year later they were at 55 lari per month. 
76. Land market. Georgia's land reform has created a reasonably equal distribution of land. The access to land is not a major factor of poverty. Only 10 percent of poor agricultural households do not cultivate land. Agricultural laborers, (landless persons who rely on wage labor on the farms of landholders), while possessing no land themselves, are almost a nonexistent class in rural Georgia. But there are some signs of rising disparities and market failures that are to be addressed by the Government.

77. By now about 60 of arable land is in private hands, with an average size of land plot belonging to rural household of about 0.75 hectares. Land reform was also largely inclusive, where today, 95 percent of rural families owning their land plots. However, there are signs of increasing concentration of land and inequality. Calculation of the Gini coefficient for land distribution yields is still moderate, but not the low level of 0.37 , yet the inequality seems to increase over time. In the middle of 1996, 20 percent of the wealthier rural population owned 23 percent of the land, whereas the poorest 20 percent had 18 percent of private cultivated land. By the end of 1997, just a year and a half later, the share of richest has increased to 25 percent, while that of the poorest eroded to 16 .

78. There is some evidence that abuse of power and local connections were behind this concentration of land rather than economic logic (Dudwick, p.40). Such noticeable changes in distribution of land in a very short period of time grabs the attention of strong interest groups favoring the redistribution of land, and shows that skepticism of small farmers in the fairness of land reform, expressed during the Qualitative assessment, is well grounded.

Figure 13.

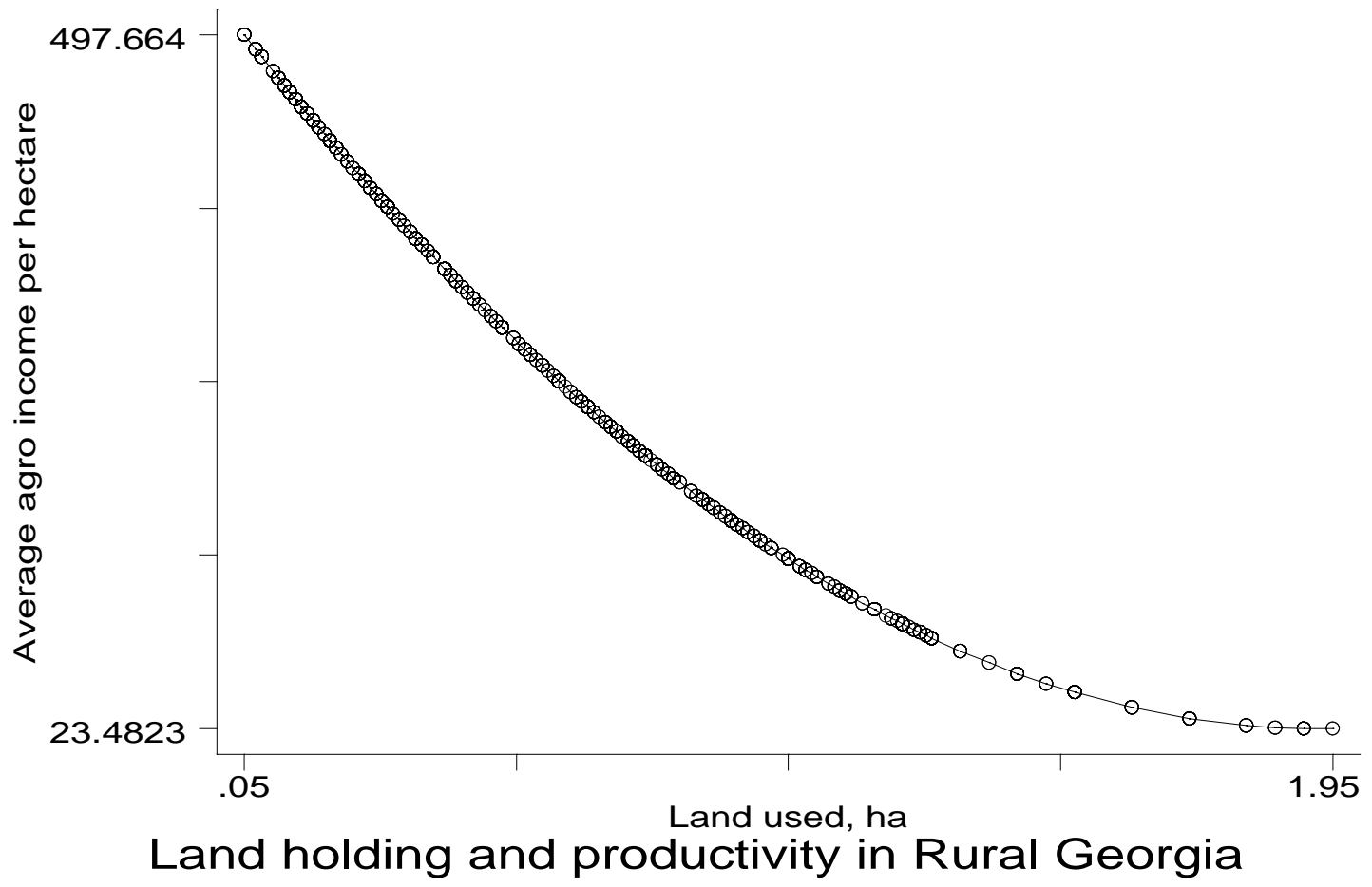

Source: SDS survey, for crops only, excluding pastures, group averages fitted by regression of productivity on holding size. 
79. Regardless of which measure of poverty we use, there is a clear relationship between the degree or extent of poverty and the household's land holdings. Thus rising inequality in the access to land is a case for concern in devising a poverty alleviation strategy.

80. Potentially the land market may play a crucial role in alleviating poverty and in increasing the efficiency of the agricultural sector. In fact, we find that smaller farmers achieve higher returns per hectare than larger farmers (see figure 13).

81. Therefore, increasing the land under cultivation by the smaller farmers through sales, lease, or rent would benefit both small and larger farmers. These transactions would be eased by the existence of a formal labor market, with clearly defined land titling and registration. In 1996, three far-reaching laws (on private ownership, titling and registration, and leasing), were adopted providing the legal basis for the functioning of a land market in the agriculture sector. The next step is the development of efficient market for land. The World Bank is supporting the on-going government efforts in this direction by providing assistance for the setting of cadasters in two districts. The challenge, however, is that 59 more districts remain in rural Georgia to be covered.

82. Rising market earnings in rural areas. Rural poverty is ultimately linked to market access. Isolated farming households that cannot exchange produce or animals to the local market, tend to be poorer than the more integrated farming households. The costs of bringing products to the market are still very high in remote areas. While we do not have data to measure the degree of isolation by infrastructure variables, we can compare the degree to which farmers use the market to buy and sell. The income from selling produce on the market tends to be higher in non-poor households than in poor. At the harvest quarter of 1997, this amounted, on average, to be 160 lari per non-poor households and 50 lari for the poor. As the rural economy is still predominantly non-market, expanding access to market will improve the living standards of many rural citizens.

83. New cooperatives can play a crucial role in raising the marketability of agricultural products. The very size of most of the land parcels (under one hectare), though granting high productivity and crucial for assuring the universal assess to land, may prove unsustainably low for commercial agriculture which requires greater uniformity of production for the market. Cooperatives or credit unions may provide much needed uniformity of inputs and marketing.

84. Agricultural information and extension services. Closeness to rural market also implies access to information, which helps farmers to use their assets, both land and labor, more productively. Information includes access to technical assistance services provided by private or public agencies (agricultural extension). One of the reasons for low productivity of rural employment is the lack of adequate technical information on advanced cultivation methods. For example, despite booming cereal production some farmers did not enjoy a rise in income, since they were planting the wheat varieties deemed not of the standard required by the bakeries, which resulted in lower prices. When the technical advice comes hand-in-hand with extending the credit to farmers, it leads to sustainable improvements in productivity.

85. Rural credit. The recent success of an extension and rural credit project to help farmers growing cereals (TACIS-RARP project) has proven the high potential of this kind of intervention to increase the efficiency of the rural sector while benefiting the poor. The project channeled in 1997 about 27 million lari to the farmers, traders and millers in the grain sector. The highest harvest of cereals in recent years was achieved manly through rising yields rather than increasing harvest areas. The encouraging trend is the high incidence of small-scale credits, particularly to 
farmers' credit unions. This effort is supported also by various international organizations, including the World Bank that implements the targeted intervention to help small farmers.

86. Conclusion to sections 2.3-2.4. Performance of labor markets across regions has been widely dissimilar. As the urban employment opportunities are still not too attractive to the rural citizens, and costs of mobility are high, (i.e., underdevelopment in main markets), there has been little rural-urban migration. But urban labor on average are better paid, and over time there seems to be an unambiguous improvement in the labor incomes in urban areas, whereas rural areas are not catching up. However, labor creation in the formal sector has been sluggish. There are therefore three areas for action: (i) facilitating business development; (ii) promoting diversification both in urban and rural areas, and (iii) increasing the productivity of labor in rural areas.

\subsection{Wage incomes: sources, distribution, and inequality}

87. Rising average real wages disguises wide inequities between workers that lead to very high inequalities in earnings. With real wage falling by 10 times, one would expect a rising compression, especially since the initial dispersion of wages under the planning regime had been restrained. However, as the response of employment to output contraction was very different in different sectors, the implied productivity changes resulted in sharp differences in the labor earnings, and inequality in earnings has increased, while real values have dropped.

88. There is evidence that earnings of women declined even more dramatically than those of men, partly because women were concentrated in the hard-hit low-paying sectors, such as education.

89. Earnings from wage employment had been bypassed by rising incomes from selfemployment, which are even more unequally distributed and unstable. All these trends have direct implications for poverty, and we are going to look at wage inequality in more detail, first by analyzing the factors behind the wage determination, and then applying a standard human capital framework to wages. The factors behind inequality in earnings from self-employment are going to be analyzed in the next chapter.

90. Wage incomes: levels and disparities. Transition has changed wage setting in a number of key respects. The tariff wage structure and the system of regional coefficients has basically collapsed. Firms were largely left to determine their own wage bargains. The non-monetary components of compensation have been declining, though subsidies to housing and energy remain important. The inequality in pay among the SOE has increased. In addition, the survey evidence indicates that private sector wages tend to be, at a minimum, higher by around 20 percent as compared to either state or privatized firms.

91. The Gini coefficient for monthly (non-zero) wages reported in SDS household survey was 0.5 for the whole period 1996-97. Taking into account time dimension even increases the inequality, and Gini for hourly wages is 0.53 . In the State sector, the inequality in hourly wage is sufficiently high 0.49 , whereas in the private sector, it is astonishingly high at .59 .

92. The average hourly wage as observed in the SDS household survey for the period of 1996-97 was 0.35 lari/hour. The median private hourly wage rate is around 50 tetris; public sector wages are only half of that. 
Figure 14.

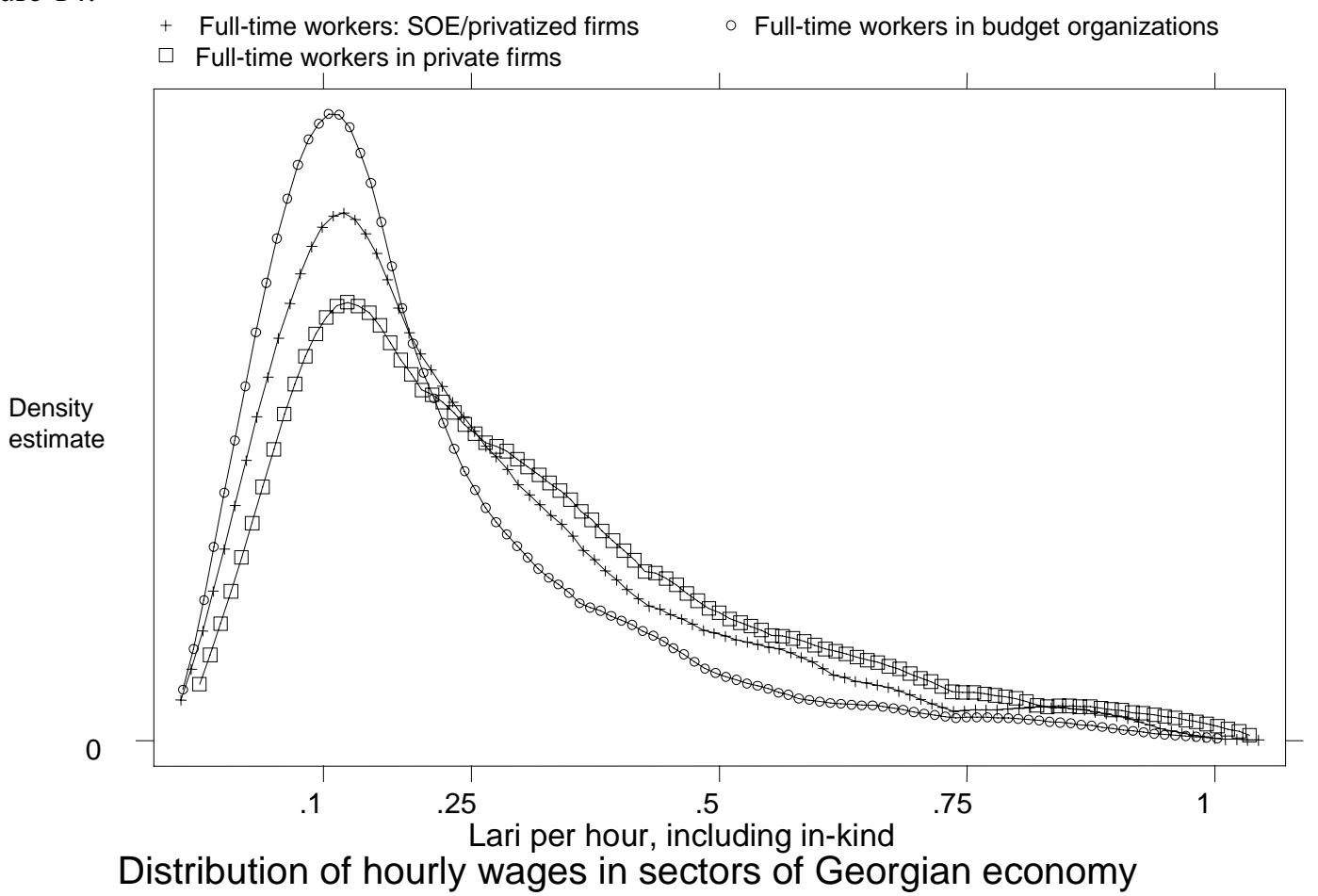

Source: SDS household survey. For full-time employees only, on average, unweighted for 2H 1996- 1H 1997.

93. Interestingly enough, this high discrepancy in wages between sectors does not mean totally different wage settings (that would mean different modes for wages), but rather the existence of more highly-paid workers in private sector. The mode and shape of the distribution of hourly wages (Figure 14) illustrate this. The modes of different sectors are in fact quite close - 12 tetris per hour in SOE, 13 in private firms and 11 in the budget sphere, implying the mode monthly salaries in a range of 18-21 lari for all sectors.

94. There are big inter-regional differences in wage in private sector; in Tbilisi the average monthly wage is 82 lari, and in Imereti and Guria, it is below 40 lari. Only 14 percent of private sector wage employment is located in these two poorest regions, while 57 percent is found in Tbilisi and Adjara.

95. Wage earnings function analysis results. We estimate a standard logarithmic earning function (both for monthly and hourly wages) where the vector of independent variables includes those indicating different levels of education, experience, current job attachment and other characteristics (Annex 1). The estimation indicates reasonably conventional returns to education. Average income is significantly and negatively associated with the current attachment to state firms and budgetary sector, agriculture, and social sectors (heath and education), as well as a rural location. There is a very substantial and significant difference in pay between men and women. Overall, however, all variables explain about 55 percent of the observed inequality (Gini for the predicted wage is .29 as opposed to actual .52). 
96. Private returns to education are nevertheless reasonably strong, as illustrated by earnings regression which includes some key exogenous variables presented in Figure 15 (see Annex 1). Private returns are strong and significant for secondary education; workers with this education command a premium over workers with incomplete secondary education. This suggests that investment in the secondary education definitely pays off in the long run, and underscores the agenda for education reform.

Figure 15.

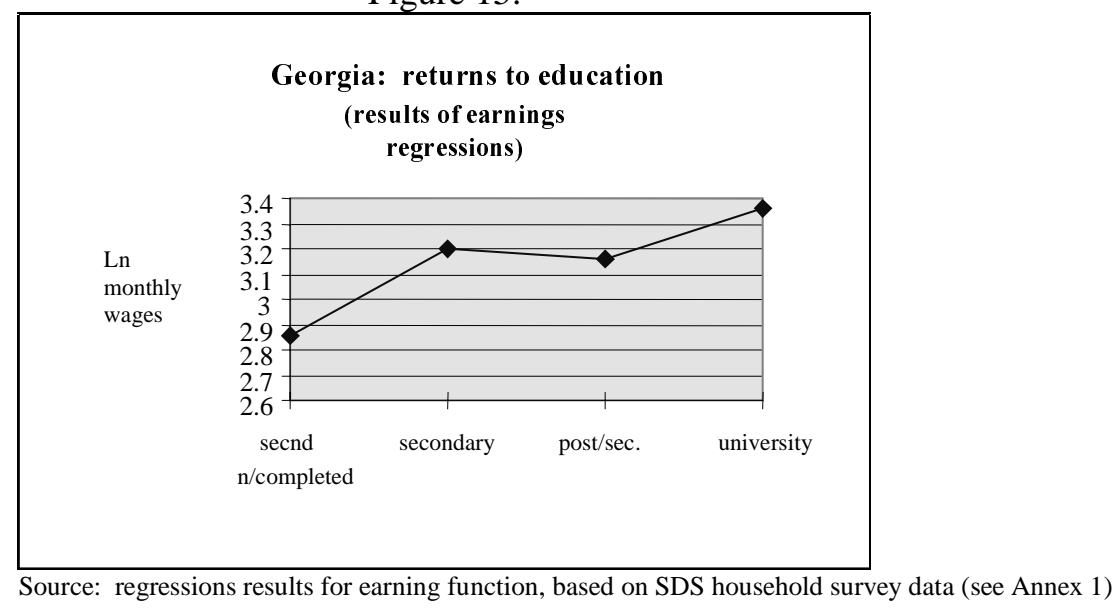

97. On the other hand, rather surprisingly, we find that the earnings differential between secondary and higher education is rather modest - barely 15 percent. This points to the poor quality of higher education and inadequate pay in some government sectors, where workers have to supplement their salary with a non-wage component. This is further highlighted by the absent premium for college-educated women, who are predominantly employed in these sectors. Since the poverty risks are approximately the same for health and education as they are for the workers employed elsewhere, it is straightforward to assume that various out-of-pocket payments make up the gap between low salary and actual take-home pay. By stimulating the effect of increasing the salary in these sectors to the average national economy level in the corresponding quarter, we arrive at an estimate of a still low 20 percent wage premium for higher education, and a gender gap of 25 percent. This shows that a limited benefit to higher education and substantial gender difference in pay is not a function of specific structure of wage employment for university graduates in the Government sector, but rather underlying social fundamentals, prevailing in many sectors of economy, and overriding sometimes market rules.

98. Conclusion. These earnings functions results are amenable to various interpretations. It was argued that in a socialist economy, the impact of educational attainment on monetary earnings was minimal, and that we might expect the shift to a market oriented economy to be associated with changes in the structure of earnings that increased the 'value' of education. At the same time, however, we might expect the structure of relative wages to be fairly rigid, and influenced by the degree of adaptation of wage market settings in the economy. It is evident that as the State sector is only slowly adjusting its payment schedules, and changes would become evident only over time. Evidence presented in this section suggests that the actual degree of adopting the market economy settings is still limited in Georgia. 


\subsection{Creating opportunities}

99. The observed pattern of employment creation and earnings growth offers some insights on what is the likely impact of economic growth in the future. As agriculture seems to be satiated with labor, further growth of output will occur mainly through the rise in use of capital and productivity. Industry may start increasing employment, but given its modest size, it will not greatly influence the overall level of employment creation. It is realistic to expect further rise in the employment in trade and services. But the overall elasticity of employment with respect to growth will certainly fall. The main channel through which the economic development should influence the living standards is going to be the rise in wages and productivity.

100. Options for helping the poor. Below is the summary of interventions that are required to ensure that economic growth will benefit the poor.

101. Granting the access education. There are clear, and probably rising in the future returns to education. Raising the quality of secondary education and designing the system to financially enable poor families to allow their children the completion of secondary education would most benefit the poor families. This would enable the children from poor families to compete more effectively on the labor market. The quality of secondary education is another issue to be addressed in the context of on-going reform.

102. Facilitating the labor market participation of women. In urban areas aiming at gradually reopening the childcare network would enable many women to work. Participation of women in the labor market in rural areas is limited by availability of jobs. Many of small-scale credit and investment and training proposals suggested by the communities entail possibilities for women to enter the off-farm sector. One the other hand, there are still unfilled vacancies in remote areas for teachers, but no one wants to move there. Designing proper incentive schemes will make a lot of rural children, now dropping out before completing secondary education, remain in school, raising the probability of their participation in the formal labor market, and also diversifying the rural economies with an increasing number of decently paid professionals.

103. Ensuring the growing wage employment by raising the attractiveness of formal employment both for employers and employees. Enforcing the legal protection of both businessmen and workers, reforming the social insurance system aiming at lower tax burden and higher compliance.

104. Enhancing productivity and sustainability of small business both in urban and rural areas by targeted credit interventions, extension services and facilitating the transfer of modern technology. 


\section{IZA Discussion Papers}

No Author(s)

161

V. Gimpelson

D. Treisman

G. Monusova

162

C. Dustmann

M. E. Rochina-

Barrachina

R. A. Hart

Y. Ma

164 M. A. Shields

S. Wheatley Price

165

A. Barrett

J. FitzGerald

B. Nolan

G. S. Epstein

A. L. Hillman

R. Winkelmann

T. K. Bauer

K. F. Zimmermann

C. Dustmann

F. Windmeijer

D. Card

D. S. Hamermesh

E. Fehr

J.-R. Tyran

M. Lofstrom

W. Meyer

Titel

Area

Date

Public Employment and Redistributive Politics:

4

$6 / 00$

Evidence from Russia's Regions

Selection Correction in Panel Data Models: An 6

Application to Labour Supply and Wages

Why do Firms Pay an Overtime Premium?

5

$6 / 00$

Racial Harassment, Job Satisfaction and Intentions

5

$6 / 00$

to Quit: Evidence from the British Nursing Profession

Immigration in a High Unemployment Economy: 1

$6 / 00$ The Recent Danish Experience

The Impact of Alcohol Consumption on Occupa- 5 tional Attainment in England

$6 / 00$

Earnings Inequality, Returns to Education and 5 Immigration into Ireland

$6 / 00$

Social Harmony at the Boundaries of the Welfare 3 State: Immigrants and Social Transfers

$6 / 00$

Immigration Policies and their Impact: The Case of 1

$7 / 00$

New Zealand and Australia

Immigration Policy in Integrated National

$7 / 00$

Economies

Wages and the Demand for Health - A Life Cycle 5

$7 / 00$

Analysis

Reforming the Financial Incentives of the Welfare 3

System

$7 / 00$

Timing, Togetherness and Time Windfalls

$7 / 00$

Does Money Illusion Matter? An Experimental

7

$7 / 00$

Approach

Self-Employment and Earnings among High-

Skilled Immigrants in the United States

Industrial Relations and the Wage Differentials

5

$7 / 00$ between Skilled and Unskilled Blue-Collar

Workers within Establishments: An Empirical

Analysis with Data of Manufacturing Firms 
177 B. R. Chiswick

G. Repetto

178 R. Euwals M. Ward

179 E. Wasmer

P. Weil

180 T. K. Bauer

I. N. Gang

181 E. Wasmer

Y. Zenou

182 M. Fertig

C. M. Schmidt

183 M. Fertig

C. M. Schmidt

184 M. Corak

B. Gustafsson

T. Österberg

185

H. Bonin

K. F. Zimmermann

186

C. Dustmann

T. K. Bauer

M. Lofstrom

K. F. Zimmermann

188 A. Kapteyn

A. S. Kalwij

A. Zaidi

189 W. Arulampalam

190

C. Dustmann

I. Preston

191

G. C. Giannelli

C. Monfardini

192

G. Brunello

A. Kunze
Immigrant Adjustment in Israel: Literacy and

Fluency in Hebrew and Earnings

The Renumeration of British Academics

The Macroeconomics of Labor and Credit Market Imperfections

Sibling Rivalry in Educational Attainment:

The German Case

Space, Search and Efficiency

2

Discretionary Measures of Active Labor Market

Policy: The German Employment Promotion Reform in Perspective

Aggregate-Level Migration Studies as a Tool for 1 Forecasting Future Migration Streams

Intergenerational Influences on the Receipt of

3

Unemployment Insurance in Canada and Sweden

The Post-Unification German Labor Market

4

$8 / 00$

Temporary Migration and Economic Assimilation

$8 / 00$

Immigration Policy, Assimilation of Immigrants and Natives' Sentiments towards Immigrants: Evidence from 12 OECD-Countries

The Myth of Worksharing

Is Unemployment Really Scarring? Effects of Unemployment Experiences on Wages

Racial and Economic Factors in Attitudes to Immigration

Joint Decisions on Household Membership and Human Capital Accumulation of Youths: The role of expected earnings and local markets

Absolute Risk Aversion and the Returns to Education

The Determination of Wages and the Gender Wage Gap: A Survey 
195 F. Büchel

A. Mertens

196 J. S. Earle

K. Z. Sabirianova

197

G. A. Pfann

198 M. Kreyenfeld

C. K. Spiess

G. G. Wagner

199 H. Entorf

200 T. Bauer

G. S. Epstein

I. N. Gang

201 T. J. Dohmen

G. A. Pfann

202

P. Francois

J. C. van Ours

203
J. M. Abowd
F. Kramarz
D. N. Margolis
T. Philippon

204

G. S. Epstein
A. L. Booth
M. Francesconi
J. Frank

206 C. M. Schmidt

R. Baltussen

R. Sauerborn

C. M. Schmidt

J. Hartog

R. Winkelmann

209 M. Barbie

M. Hagedorn

A. Kaul

210 T. J. Dohmen
Overeducation, Undereducation, and the Theory

of Career Mobility

Equilibrium Wage Arrears: A Theoretical and 4

Empirical Analysis of Institutional Lock-In

Options to Quit

1

$9 / 00$

A Forgotten Issue: Distributional Effects of Day 3

Care Subsidies in Germany

Rational Migration Policy Should Tolerate Non-

Zero Illegal Migration Flows: Lessons from

Modelling the Market for Illegal Migration

What are Migration Networks?

$9 / 00$

Worker Separations in a Nonstationary Corporate 1 Environment

Gender Wage Differentials in a Competitive Labor Market: The Household Interaction Effect

The Tail of Two Countries: Minimum Wages and 5 Employment in France and the United States

5

$9 / 00$

$9 / 00$

Labor Market Interactions Between Legal and

1

$10 / 00$ Illegal Immigrants

Temporary Jobs: Stepping Stones or Dead Ends? 1

$10 / 00$

The Evaluation of Community-Based Interventions: Group-Randomization, Limits and Alternatives

Arbeitsmarktpolitische Maßnahmen und ihre

6

$10 / 00$

Evaluierung: eine Bestandsaufnahme

Dutch Migrants in New Zealand:

Did they Fare Well?

1

$10 / 00$

Dynamic Effciency and Pareto Optimality in a

3

$10 / 00$ Stochastic OLG Model with Production and Social Security 

211 A. van Soest
M. Das
X. Gong
212 X. Gong
A. van Soest
P. Zhang
213 X. Gong
A. van Soest
E. Villagomez

214 X. Gong

A. van Soest

215 J. Ermisch

M. Francesconi

216 F. Büchel

217 J. Hansen

R. Wahlberg

218 C. Dustmann

A. van Soest

219 F. Kramarz

T. Philippon

220 W. A. Cornelius

E. A. Marcelli

221

C. Grund

222 W.P.M. Vijverberg

223 M. Rosholm

M. Svarer

224

J. Schwarze

225

L. Modesto

J. P. Thomas
A Structural Labour Supply Model with

The Effects of Overeducation on Productivity in Mexico

Wages as Risk Compensation in Germany 

former Soviet Union to Israel: Who is coming when? 

of Labor Income Risk and Car Insurance in the UK 1969-95 Soviet Union: A Study of the Suicide Epidemic in the 1990s

244 S. M. Fuess, Jr.

Pay and Productivity in a Corporatist Economy: 